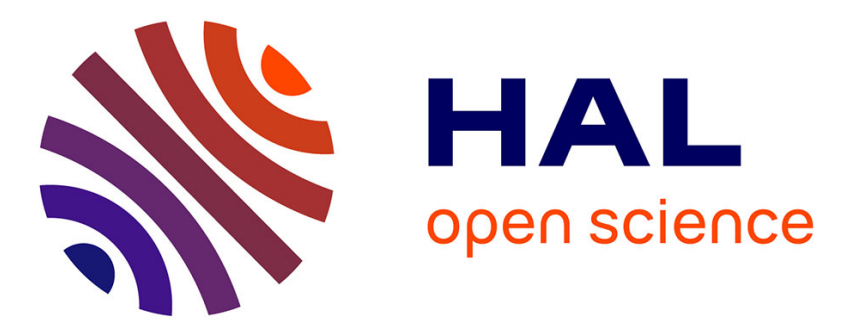

\title{
Are small mountainous tropical watersheds of oceanic islands important for carbon export?
}

\author{
E. Lloret, C. Dessert, E. Lajeunesse, O. Crispi, L. Pastor, J. Gaillardet, M. F.
} Benedetti

\section{- To cite this version:}

E. Lloret, C. Dessert, E. Lajeunesse, O. Crispi, L. Pastor, et al.. Are small mountainous tropical watersheds of oceanic islands important for carbon export?. Biogeosciences Discussions, 2012, 9, pp.7117-7163. 10.5194/bgd-9-7117-2012 . insu-03583345

\section{HAL Id: insu-03583345 \\ https://hal-insu.archives-ouvertes.fr/insu-03583345}

Submitted on 22 Feb 2022

HAL is a multi-disciplinary open access archive for the deposit and dissemination of scientific research documents, whether they are published or not. The documents may come from teaching and research institutions in France or abroad, or from public or private research centers.
L'archive ouverte pluridisciplinaire HAL, est destinée au dépôt et à la diffusion de documents scientifiques de niveau recherche, publiés ou non, émanant des établissements d'enseignement et de recherche français ou étrangers, des laboratoires publics ou privés. 


\section{Are small mountainous tropical watersheds of oceanic islands important for carbon export?}

E. Lloret ${ }^{1,{ }^{*}}$, C. Dessert ${ }^{2,3}$, E. Lajeunesse ${ }^{4}$, O. Crispi $^{3}$, L. Pastor ${ }^{1}$, J. Gaillardet ${ }^{2}$, and $M$. F. Benedetti ${ }^{1}$

${ }^{1}$ Equipe Géochimie des Eaux, Université Paris Diderot, Sorbonne Paris Cité, IPGP, UMR 7154, CNRS, 75205 Paris, France

${ }^{2}$ Equipe de Géochimie et Cosmochimie, Université Paris-Diderot, Sorbonne Paris Cité, IPGP, UMR 7154, CNRS, 75205 Paris, France

${ }^{3}$ Observatoire Volcanologique et Sismologique de Guadeloupe (OVSG) IPGP, UMR 7154, CNRS, Le Houëlmont, 97113 Gourbeyre, Guadeloupe (FWI)

${ }^{4}$ Equipe de Dynamique des Fluides Géologiques, Université Paris-Diderot, Sorbonne Paris Cité, IPGP, UMR 7154, CNRS, 75205 Paris, France

*now at: Department of Renewable Resources, University of Alberta, 442 Earth Sciences Building, Edmonton, AB T6G 2E3, Canada

Received: 2 May 2012 - Accepted: 10 May 2012 - Published: 18 June 2012

Correspondence to: E. Lloret (lloret@ualberta.ca) or M. F. Benedetti (benedetti @ipgp.fr)

Published by Copernicus Publications on behalf of the European Geosciences Union.

Tropical oceanic islands carbon export

E. Lloret et al.

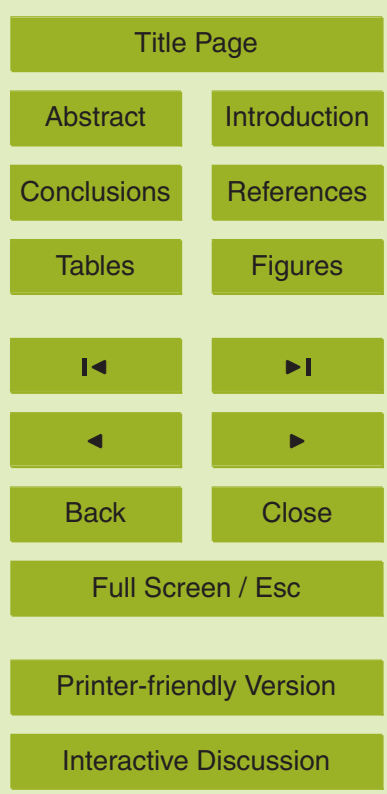




\section{Abstract}

In the tropic, the small watersheds are affected by intense meteorological events playing an important role on the erosion of soils and therefore on the associated organic carbon fluxes. We studied the geochemistry of three small watersheds around the

5 Basse-Terre volcanic Island (FWI) during a four years period, by measuring DOC, POC and DIC concentrations. The mean annual yields ranged $8.1-15.8 \mathrm{tC} \mathrm{km}^{-2} \mathrm{yr}^{-1}, 1.9-$ $8.6 \mathrm{tC} \mathrm{km}^{-2} \mathrm{yr}^{-1}$ and $8.1-25.5 \mathrm{tC} \mathrm{km}^{-2} \mathrm{yr}^{-1}$ for DIC, DOC and POC, respectively. Floods and extreme floods represent 45 to $70 \%$ of the annual DOC flux, and more than $80 \%$ of the annual POC flux. The DIC flux occurs essentially during the low water level, only $43 \%$ of the annual DIC flux is exported during floods. The distribution of the dissolved carbon between the inorganic and the organic fraction is correlated to the hydrodynamic of rivers. During low water level and floods, the dissolved carbon is exported under the inorganic form (DIC/DOC $=2.6 \pm 2.1$ ), while during extreme floods, the dissolved carbon transported is mostly organic ( $\mathrm{DIC} / \mathrm{DOC}=0.7 \pm 0.2)$. The residence time

15 of the organic carbon in Guadeloupean soils may vary from 381 to $1000 \mathrm{yr}$, and is linked to the intensity of meteorological events than the frequency of meteorological events. Looking at the global carbon mass balance, the total export of organic carbon coming from small tropical and volcanic mountainous rivers is estimated about 2.08.9 $\mathrm{TgCyr}^{-1}$ for DOC and about 8.4-26.5 $\mathrm{TgCyr}^{-1}$ for POC, emphasizing that these carbon fluxes are significant and should be included in global carbon budgets.

\section{Introduction}

Soil organic matter contains 1400 to $1500 \mathrm{Gt}$ of carbon and is one of the major pools of carbon at the Earth surface (Schlesinger, 1977; Gregory et al., 1999). Soil erosion thus represents the major input of organic carbon in aquatic ecosystems and a major leak for terrestrial ecosystems. During meteorological events, soil organic carbon (SOC) can be lixiviated and transferred in aquatic ecosystem in dissolved form, or can

\section{BGD}

9, 7117-7163, 2012

Tropical oceanic islands carbon export

E. Lloret et al.

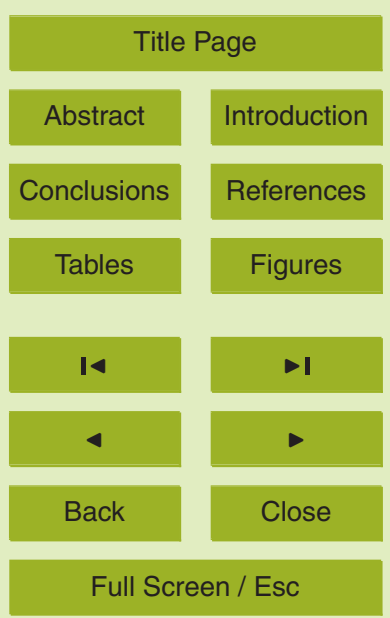

Printer-friendly Version

Interactive Discussion 
be eroded and transferred in aquatic ecosystem or translocated over the landscape in particulate form (Lal, 2004). During its transport in rivers to the oceans, terrestrial organic carbon can be mineralized and/or exported into the ocean (DOC and POC), or deposited and stored (POC) in aquatic ecosystems under low discharge (i.e.: allu5 vial plains, mangroves) (Lal, 2004). Once in the ocean, this terrestrial organic matter is then mineralized, and/or buried in sediments, and/or transported offshore (Hedges et al., 1997). Having been subjected to severe microbial attack in soils (Oades, 1988; Hedges et al., 1994) and aquifers (e.g., Nelson et al., 1993), riverine DOC and POC arriving in estuaries and seas can be recalcitrant and resist to the degradation in these 10 ecosystems. Nevertheless, studies have shown that less than one-third of terrestrial organic carbon is buried in marine sediments and stored over geological timescales (Berner, 1989; Hedges and Keil, 1995; Hedges et al., 1997; Schlünz and Schneider, 2000; Gordon and Goñi, 2004; Burdige, 2005; Galy et al., 2007).

Organic carbon transport from continents to oceans represents around $40 \%$ of the 15 global continental carbon flux varying between 0.4 and $0.9 \mathrm{Gtyr}^{-1}$ (Hedges et al., 1997; Schlünz and Schneider 2000; Aitkenhead-Peterson et al., 2003), with about $60 \%$ in the dissolved form (DOC) and $40 \%$ in the particulate form (POC). Uncertainties on the estimation of the global organic carbon transfer are partly due to the lack of holistic quantitative studies taking into account all sizes of watersheds as well as all type of climatic regimes. Indeed studies generally focus on large river systems like the Mississippi (Bianchi et al., 2007; Duan et al., 2007), the Ganga-Brahmaputra (Galy et al., 2008), tributaries of the Amazon River (Moreira-Turcq et al., 2003; Johnson et al., 2006; Aufdenkampe et al., 2007; Bouchez et al., 2010), large Arctic rivers (Yenisei, Ob, Lena Rivers) (Ludwig et al., 1996a; Dittmar and Kattner, 2003; Gebhardt et al., 2004; Raymond et al., 2007), ... which integrate differences in lithology, vegetations, soils and climate. However, small mountainous rivers directly connected to the oceans are less studied than large rivers, although they play an important role in transporting organic matter, their yields and runoff being inversely proportional to the watershed area (Walling, 1983; Milliman and Meade, 1983; Degens and Ittekkot, 1985; Milliman
BGD

9, 7117-7163, 2012

Tropical oceanic islands carbon export

E. Lloret et al.

Title Page

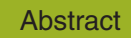

Introduction

Conclusions

Tables

References

Figures

14

$\rightarrow$

4

Back

Close

Full Screen / Esc

Printer-friendly Version

Interactive Discussion 
and Syvitski, 1992). Recent works have demonstrated that these small rivers are major sources of POC (Kao and Liu, 1996; Schlünz and Schneider, 2000; Lyons et al., 2002; Carey et al., 2005; Hilton et al., 2008b), DOC (Lloret et al., 2011) and dissolved major elements to the oceans (Louvat and Allègre, 1997; Dessert et al., 2009; Goldsmith 5 et al., 2010; Calmels et al., 2011; Lloret et al., 2011). Numerous small mountainous rivers are affected by aperiodic intense precipitation events such as cyclones or tropical storms that can play an important role on the erosion of soils and the flux of total organic carbon released by these systems (Waterloo et al., 2006; Dawson et al., 2008; Goldsmith et al., 2008; Hilton et al., 2008a; Lloret et al., 2011).

10 From these observations, the Guadeloupe Island (French West Indies) is an ideal location to study the yield and the flux of carbon from such small watersheds as well as the impact of these events on inorganic and organic carbon fluxes. Its monolithologic volcanic composition helps to constrain the influence of other factors such as climate, soil composition, and age of the bedrock. In addition, high rates of chemical weathering and mechanical denudation are reported for volcanic lithology (Louvat and Allègre, 1997; Dessert et al., 2001, 2003; Rad et al., 2007; Goldsmith et al., 2010; Gaillardet et al., 2012). Moreover, Guadeloupean soils (andosol and ferralitic soils) (Colmet-Daage and Bernard, 1979) present enriched surface horizons in organic matter (10-15\%) (Colmet-Daage and Lagache, 1965; Duchaufour, 2001). Guadeloupean coasts are impacted by numerous meteorological events like tropical storms and cyclones (Saffache et al., 2003; Zahibo et al., 2007). Previous studies showed that the soil erosion could be accentuated by these extreme meteorological events (Waterloo et al., 2006; Dawson et al., 2008; Hilton et al., 2008a; Lloret et al., 2011). Lloret et al. (2011), focusing on spatial and temporal distribution of dissolved inorganic carbon (DIC) and on the carbon export, more than $50 \%$ of the annual DOC export being transported during floods. During floods, rivers are fed by surface solutions enriched in DOC resulting from lixiviation of freshly deposited organic matter. Under low water conditions, the ground flow path is the major source of organic carbon and explains the low DOC
BGD

9, 7117-7163, 2012

Tropical oceanic islands carbon export

E. Lloret et al.

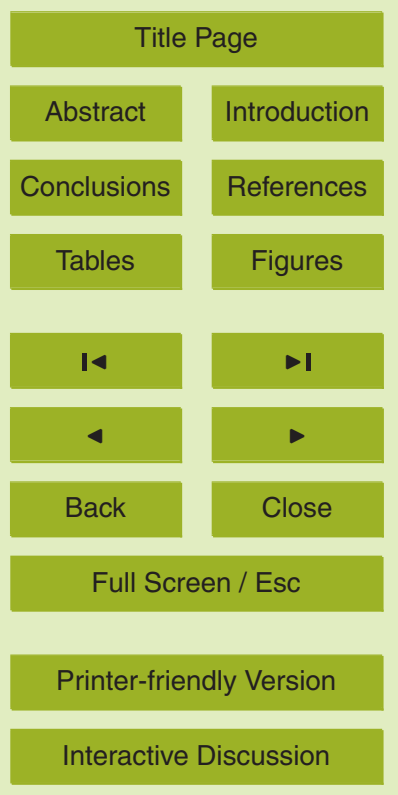


concentrations. They also estimated that DOC yields by small volcanic and mountainous islands under tropical climate ranges between 2.5 and $5.7 \mathrm{tkm}^{-2} \mathrm{yr}^{-1}$ and is similar to the DOC yields calculated for large tropical rivers like the Amazon $\left(5.8 \mathrm{tkm}^{-2} \mathrm{yr}^{-1}\right)$ (Moreira-Turq et al., 2003), the Orinoco and the Parana (4.8 and $1.4 \mathrm{tkm}^{-2} \mathrm{yr}^{-1}$, respec5 tively) (Ludwig et al., 1996b and references therein). However in Lloret et al. (2011), the POC yields were not considered and then the global export of organic carbon was not estimated.

The aims of this paper are, on the light of POC, DOC, and DIC and particulate nitrogen (PN) concentrations, (1) to calculate the annual yields and fluxes of these different carbon forms, (2) to estimate the impact of the floods on the global carbon export, (3) to characterize the hydrodynamic of the different carbon forms (POC vs. DOC and DIC vs. DOC), related to flood type (associated with different meteorological event), (4) to estimate the carbon mass balance at watershed scale and calculate the residence time of carbon in soil and aboveground biomass and soils, (5) to compare 15 the carbon fluxes from small tropical watersheds with the one of large rivers.

To address these issues, we have selected three watersheds, hydrologically monitored for several decades, with various size, elevation, ages, slope, and exposure to rainfalls. One of these rivers was monitored intensively with an automatic water sampler equipped with pressure sensor activated during flood events, increasing significantly

\section{Site characteristics}

The main characteristics of the watersheds are given in Table A1 and summarized in Fig. 1.

These three watersheds are studied as part of the ObsErA (INSU-CNRS; AllEnvi) observatory devoted to the study of weathering and erosion in the French West Indies. This observatory itself belongs to the French network of monitored watersheds (RBV supported by INSU-CNRS and AllEnvi). The three watersheds are located in the

\section{BGD}

9, 7117-7163, 2012

Tropical oceanic islands carbon export

E. Lloret et al.

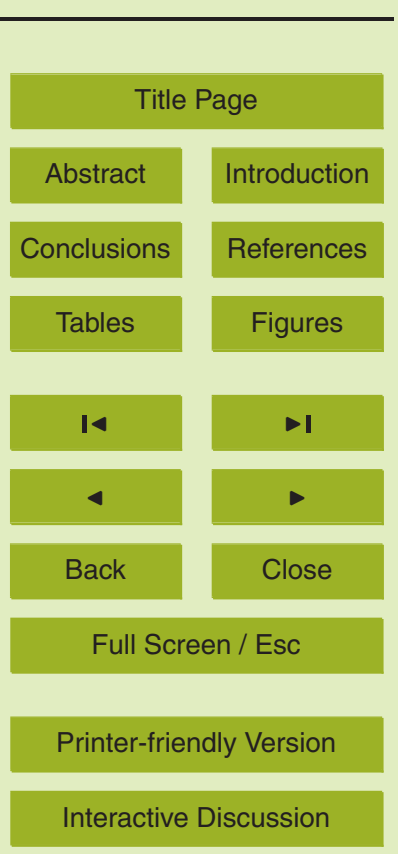


National Park of Guadeloupe in the central part of the volcanic Basse-Terre Island. The vegetation is mainly dominated by tropical rainforest and by altitude forest type at the head of watersheds (Rousteau et al., 1994; Rousteau, 1996).

The Bras-David watershed located in the center of Basse-Terre Island is essentially 5 composed of Pliocene andesitic and dacitic formations (Samper et al., 2007), covered by a very thick ferralitic soil (Colmet-Daage and Bernard, 1979). Soils of the site were previously studied (Buss et al., 2010; Sak et al., 2010) and consist of highly weathered volcanoclastic debris flows, containing rocky clasts at various stages of weathering. Clays, dominantly halloysite, represent about $75 \mathrm{wt} \%$ of the mineralogy and nonclays 10 are almost entirely $\mathrm{Fe}(\mathrm{III})$-hydroxides and quartz/cristobalite. The average $\mathrm{C} / \mathrm{N}$ ratio is $12.9 \pm 3.4$ (Lloret, 2010). The Capesterre and Vieux-Habitants watersheds, located respectively in the southeastern and southwestern parts of Basse-Terre, are underlain by andesitic rocks linked to Pliocene and Quaternary volcanism (Samper et al., 2007) and covered with thin andosol ( $<1 \mathrm{~m}$ ) (Colmet-Daage and Bernard, 1979; Cattan et al., 15 2007), related to the steep slopes of the young volcanic rocks. The average $\mathrm{C} / \mathrm{N}$ ratio is $11.8 \pm 1.6$ (Lloret, 2010).

The Basse-Terre Island is characterized by a wet tropical climate, with a mean annual temperature around $23^{\circ} \mathrm{C}$ and humidity of $75 \%$. The average annual precipitation for the last $20 \mathrm{yr}$ ranges from 1200 to $8000 \mathrm{~mm} \mathrm{yr}^{-1}$, depending on the topography, and can vary annually. Years are punctuated by a dry season from January to June and a wet rainy season from July to December. During the wet season, hurricanes and tropical depressions produce individual rainfall events, which play a major role on the erosion of Guadeloupean soils and weathering products. As shown in Fig. 1, the spatial distribution of precipitations is strongly influenced by easterly and topography. We collected precipitation data of three Météo-France pluviometers close to our sampling points (Petit-Bourg Duclos, Capesterre-Belle-Eau Neufchâteau and Vieux-Habitants Gendarmerie Beausoleil) and of the OVSG-IPGP meteorological station at the summit of La Soufrière volcano ( $1463 \mathrm{~m}$, the highest point of the Lesser Antilles). The maximum of precipitation is recorded at the top of the volcano, with annual cumulated rainfalls

\section{BGD}

9, 7117-7163, 2012

Tropical oceanic islands carbon export

E. Lloret et al.

\section{Title Page}

\section{Abstract}

Introduction

Conclusions

Tables

References

Figures

14

$\rightarrow 1$

4

Back

Close

Printer-friendly Version

Interactive Discussion 
varying between 4100 and $5100 \mathrm{~mm}$ during the 2007-2010 studied period. The BrasDavid and Capesterre watersheds are located on the windward coast influenced by easterly and present also high annual precipitations, between 2000 and $4300 \mathrm{~mm} \mathrm{yr}^{-1}$. The Vieux-Habitants watershed, located on the leeward coast, receives on average $51100 \mathrm{~mm} \mathrm{yr}^{-1}$ of rainfalls near the sampling location. Capesterre and Vieux-Habitants watersheds have the same basin head, where they receive the same annual cumulated rainfalls (about $4000 \mathrm{mmyr}^{-1}$ ).

The discharges of the studied rivers are monitored by the DEAL (French Water Survey agency; http://www.hydro.eaufrance.fr). The Fig. 1 shows the variations of the 10 instantaneous discharges for the three rivers during the 2007-2010 period. The instantaneous discharge of Bras-David River ranges from 0.2 to $25.7 \mathrm{~m}^{3} \mathrm{~s}^{-1}$, those of Capesterre River from 0.5 to $119.7 \mathrm{~m}^{3} \mathrm{~s}^{-1}$, and those of Vieux-Habitants River from 0.5 to $44.9 \mathrm{~m}^{3} \mathrm{~s}^{-1}$. Flood events occurred throughout the years, but they were in greater numbers during the wet season. We can observe significantly high discharges dur15 ing strong rainy events and tropical storms like the DEAN cyclone (17 August 2007), and two storms that occurred on the 05 May 2009 and the 19 June 2010. Based on the DEAL discharge dataset and according to the frequency of discharges, we determined that studied rivers are in flood during $10 \%$ of the year (Lloret et al., 2011), and in extreme flood during $0.1 \%$ of the year. Rivers are then considered in flood when discharge exceeds $3.9 \mathrm{~m}^{3} \mathrm{~s}^{-1}, 1.3 \mathrm{~m}^{3} \mathrm{~s}^{-1}$, and $2.6 \mathrm{~m}^{3} \mathrm{~s}^{-1}$ and in extreme flood when discharge exceeds $37.0 \mathrm{~m}^{3} \mathrm{~s}^{-1}, 9.0 \mathrm{~m}^{3} \mathrm{~s}^{-1}$, and $18.0 \mathrm{~m}^{3} \mathrm{~s}^{-1}$ for Capesterre River, BrasDavid River and Vieux-Habitants River, respectively. The number of days when the rivers were in flood and in extreme flood is listed in Table A1.
BGD

9, 7117-7163, 2012

Tropical oceanic islands carbon export

E. Lloret et al.

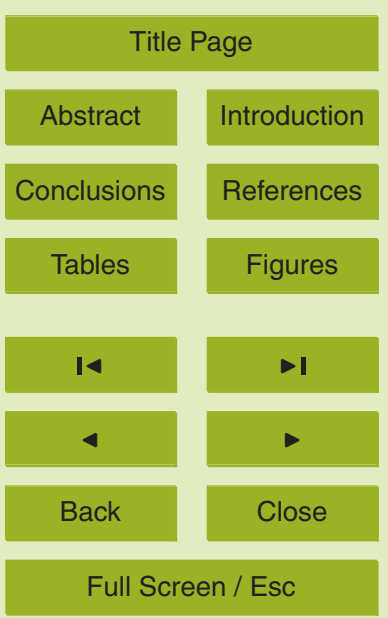

Printer-friendly Version

Interactive Discussion 


\section{Methodology}

\subsection{Sample collection}

Pristine water samples were collected, upstream of any anthropogenic activities (Fig. 1). The sampling of surface water was done manually from 2007 to 2010 at different hydrological stages corresponding to low water levels and floods for the three rivers. An automatic water sampler, ISCO-6712, was set up on the Capesterre River. The temporal variation from one flood to another flood was explored and for each event, 12 or 24 samples were taken with a time step ranging from $15 \mathrm{~min}$ to $2 \mathrm{~h}$ (from beginning to end of the flood). We were able to collect 27 flood events including 5 extreme 10 events.

An important aspect of our investigation is to assess whether our river sampling covers a representative range of flow rates. This was done by comparing the distribution of flow discharges to the distribution of sampled discharges for each river on Fig. 2. The distributions of flow discharges were calculated using the flow rate chronicles of the "Direction Regionale de l'Environnement". Figure 2 clearly shows that the use of an automatic water sampler allowed us to cover a representative range of flow rates in the case of the Capesterre River. This is not the case for Bras-David and Vieux-Habitants Rivers as the difficulty of performing manual sampling during floods prevented us from sampling high discharges.

20 Samples used for the measurement of dissolved organic carbon concentrations were filtered through glass fiber filters (GF/F Whatman ${ }^{\circledR}$ by Schleicher \& Schuell cut off $0.7 \mu \mathrm{moll}^{-1}$ ), acidified with concentrated $\mathrm{H}_{3} \mathrm{PO}_{4}$ in pre-cleaned and pre-combusted glass bottles and stored at $4{ }^{\circ} \mathrm{C}$ in the dark. Filters with the total suspended matter (TSM) were dried at $60^{\circ} \mathrm{C}$ and stored in Petri Dish.

Tropical oceanic islands carbon export

E. Lloret et al.

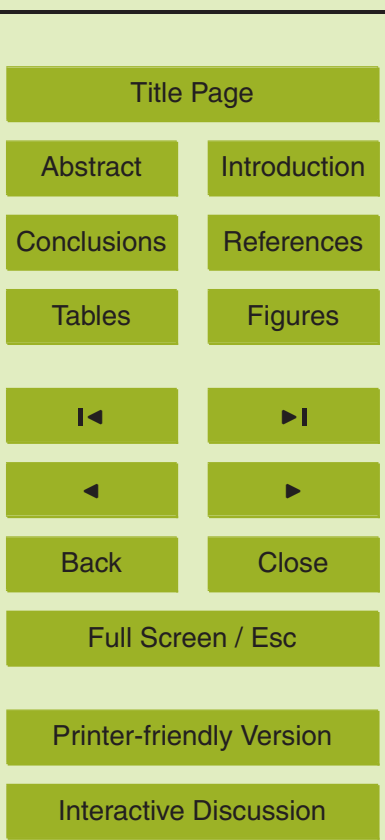




\subsection{Analytical methods}

Temperature, $\mathrm{pH}$ and conductivity were measured in-situ. Alkalinity values were measured at the laboratory with an automatic acid-base titration stand (Radiometer TIM840 with Schott probe) by the Gran method with a precision of $1 \%$.

5 TSM concentrations ( $\mathrm{mgl}^{-1}$ ) were measured on pre-weighted GF/F filters and dried at $60^{\circ} \mathrm{C}$ before and after the filtration. POC and PN were assessed directly from GF/F filters. One eighth of each filter was weighed $( \pm 0.001 \mathrm{mg} \mathrm{DW})$ and analyzed in a CHNS-Thermofisher analyzer, after overnight (12 h) acidification under concentrated $\mathrm{H}_{3} \mathrm{PO}_{4}$ acid vapor prior to the determination of organic carbon. The precision was $10<5 \%$. Dissolved organic carbon (DOC) concentrations were measured using a Shimadzu TOC-VCSH analyzer (Sugimura and Suzuki, 1988). The detection limit was $20 \mathrm{mmolI}^{-1}$ and the precision was $2 \%$.

\section{Results}

\subsection{Carbon distribution for the three watersheds}

15 The minimum, maximum and average concentrations of dissolved fraction (DIC, DOC) and particulate fraction (TSM, POC and PN) are reported in Table A2, as well as the corresponding number of samples analyzed.

The solid transport, associated to the soil erosion, mainly occurs during floods. TSM concentrations for the three rivers range between 6 and $476 \mathrm{mgl}^{-1}$ (Table A2) and are in agreement with values from subtropical mountainous rivers in Taiwan (TSM from 2 to $4000 \mathrm{mgl}^{-1}$ ) (Kao and Liu, 1996), tropical mountainous watersheds of Puerto Rico (TSM $=6.96$ to $61.8 \mathrm{mgl}^{-1}$ ) (McDowell and Asbury, 1994), or temperate mountainous river in New Zealand (9.6-660.3 $\mathrm{mgl}^{-1}$ ) (Hilton et al., 2008b). POC concentrations in the three rivers range between 0.3 and $75 \mathrm{mg} \mathrm{Cl}^{-1}$ (Table A2) and represent between 3.5 and $23.5 \%$ of the TSM (Fig. A1). They are significantly higher than values reported

\section{BGD}

9, 7117-7163, 2012

Tropical oceanic islands carbon export

E. Lloret et al.

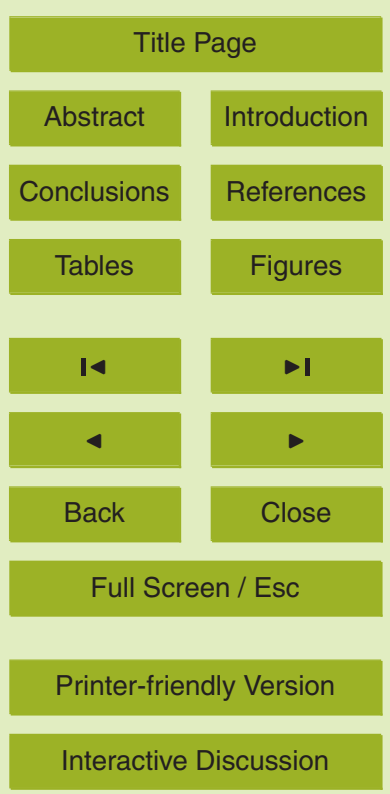


in a subtropical mountainous river in Taiwan (0.1-30 $\left.\mathrm{mgl}^{-1}\right)$ (Kao and Liu, 1996), in tropical mountainous watersheds of Puerto Rico (0.19-1.73 $\left.\mathrm{mgl}^{-1}\right)(\mathrm{McDowell}$ and Asbury, 1994), or in a temperate mountainous river in New Zealand $\left(0.10-2.25 \mathrm{mgl}^{-1}\right.$ ) (Hilton et al., 2008b). These high values are the results of the intense erosion in this 5 system. PN concentrations range between 0.02 and $4.9 \mathrm{mgl}^{-1}$ and are significantly higher than data obtained for Puerto Rico (0.02-0.08 $\mathrm{mgl}^{-1}$ ) (McDowell and Asbury, 1994). The mean annual $\mathrm{C} / \mathrm{N}$ ratio varies between $13.7 \pm 0.8$ and $16.4 \pm 4.3$ and is similar to the $\mathrm{C} / \mathrm{N}$ ratio of local soils given in the site description section.

All watersheds have the same DOC concentrations, between 29 and $479 \mathrm{umoll}^{-1}$

10 (Table A2). DOC concentrations are similar to the one measured for small mountainous rivers of New Zealand $\left(\approx 200 \mathrm{mmoll}^{-1}\right.$ ) (Carey et al., 2005), and for tropical mountainous rivers of Puerto Rico ( $\left.\approx 110-180 \mathrm{\mu moll}^{-1}\right)$ (McDowell and Asbury, 1994), and in tributaries of the Amazon (Mounier et al., 2002; Moreira-Turcq et al., 2003).

The contribution of the organic matter in the measure of the alkalinity could have an influence on $\mathrm{CO}_{2}$ fluxes and weathering rates calculations. The titrations of alkalinity include some reactive site of the dissolved organic matter, and thus can overestimate the final result especially when the DOC contribution becomes important. A correction is then needed to remove its contribution to the measured alkalinity. The charge of organic matter is estimated using the NICA-Donnan model (Benedetti et al., 1996). Assuming 20 that the organic matter is mainly composed of fulvic acid as in natural ecosystem and that $70 \%$ of this organic matter is reactive (Jouvin et al., 2009), then the amount of protons consumed during the titration by the organic matter is calculated and the alkalinity can be corrected.

For the Capesterre River, Bras-David River and Vieux-Habitants River, the contribu25 tion of the organic matter represents respectively 0.3 to $16.1 \%, 0.2$ to $10.6 \%$, and 0.2 to $4.9 \%$ of the measured alkalinity.

The calculations of DIC are made using in-situ $\mathrm{pH}$, temperature, corrected alkalinity and ionic strength measurements performed in the laboratory. The following simplified
BGD

9, 7117-7163, 2012

Tropical oceanic islands carbon export

E. Lloret et al.

\section{Title Page}

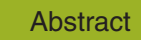

Introduction

Conclusions

Tables

References

Figures

14

$\rightarrow$

4

Back

Close

Printer-friendly Version

Interactive Discussion 
formula (neglecting concentrations of $\mathrm{OH}^{-}$and $\mathrm{H}^{+}$) is then used:

$\mathrm{DIC}=\frac{\mathrm{Alk}_{\mathrm{cor}}}{\frac{1}{\left.1+\gamma_{1} \cdot 10^{(\mathrm{pK} \mathrm{A} 1}-\mathrm{pH}\right)+\frac{\gamma_{1}}{\gamma_{2}} \cdot 10^{(\mathrm{pH}-\mathrm{pK}}}+\frac{2}{1+\frac{\gamma_{2}}{\gamma_{1}} \cdot 10^{\left(\mathrm{pK}_{\mathrm{A} 2}-\mathrm{pH}\right)}+\gamma_{2} \cdot 10^{\left(\mathrm{pK}_{\mathrm{A} 1}+\mathrm{pK}_{\mathrm{A} 2}-2 \mathrm{pH}\right)}}}$

BGD

with Alk $_{\text {cor }}=$ alkalinity corrected of organic acids, $\gamma_{1}$ and $\gamma_{2}=$ activity coefficients of ions mono-charged or bi-charged, $\mathrm{K}_{\mathrm{A} 1}$ and $\mathrm{K}_{\mathrm{A} 2}=$ first and second acidity constants of 5 carbonate system, respectively.

Calculated DIC concentrations range between 65 and $726 \mu \mathrm{molCl}^{-1}$ for the Capesterre River, 163 and $698 \mu_{\mathrm{molCl}}^{-1}$ for the Bras-David River, 192 and $574 \mu_{\mathrm{mol} \mathrm{Cl}}^{-1}$ for the Vieux-Habitants River (Table A2). They are similar from one year to another and are similar to results obtained in other parts of Guadeloupe by

10 Lloret et al. (2011), for other volcanic islands as Mont Serrat and the Dominica (Goldsmith et al., 2010; Gaillardet et al., 2012), and to the lowest values measured in Mount Cameroun rivers (Benedetti et al., 2003) and the Réunion rivers (Louvat and Allègre, 1997), where the alkalinities are not DOC contribution corrected.

\subsection{Monthly variations for Capesterre River}

15 The large number of measurements obtained on Capesterre River from the automatic sampler allows a better resolution of temporal variations and thus a better resolution in chemical fluxes calculations. Average monthly concentrations $\left(C_{\mathrm{m}}\right)$ of TSM, POC, PN, DIC and DOC were calculated from instantaneous concentrations $\left(C_{\mathrm{i}}\right)$ and instantaneous discharge $\left(Q_{\mathrm{i}}\right)$, using the formula:

Tropical oceanic islands carbon export

E. Lloret et al.

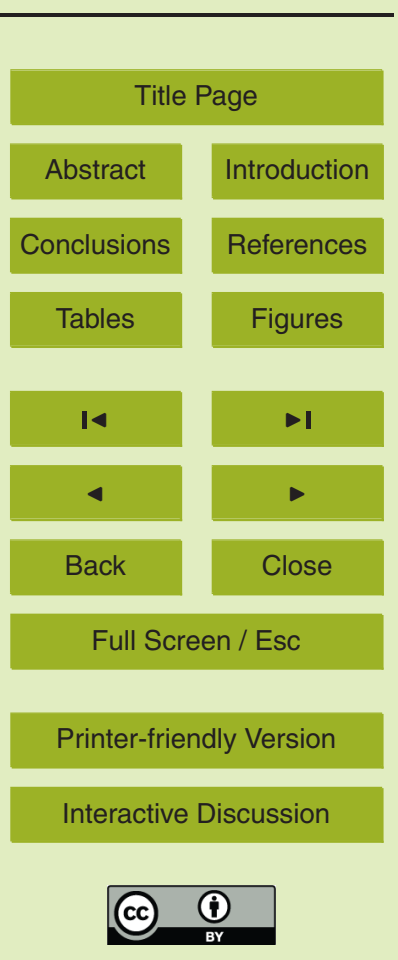


Results are reported in Fig. 3. The monthly DIC concentrations (Fig. 3a) vary conversely to the discharge, indicating a partial dilution effect with high discharges. The monthly DOC concentrations (Fig. 3a) reveal a seasonal pattern, with minimum values calculated for the driest months (January, February or March; median $=80 \mathrm{\mu moll}^{-1}$ ), 5 and maximum values calculated for the most rainy months (August, September and October; median $=180 \mathrm{umolI}^{-1}$ ). The monthly particulate concentrations (TSM and POC) and $\mathrm{C} / \mathrm{N}$ ratios (Fig. $3 \mathrm{~b}$ ) in river do not reveal a seasonal trend, with generally little variations from one month to another. The lack of seasonality in suspended transport could be related to a combined effect of the timing of the event and its strength with respect to the previous events in the year.

\subsection{Concentration-discharge relationship}

In the specific hydrological context of mountainous and tropical Guadeloupean rivers, the timing of sample collection is critical. As an illustration of the temporal variations, the extreme flood from 17 August 2007, associated to Dean Cyclone of Capesterre River 15 is shown on Fig. 4. The overall global sampling time is one day and the discharge increases from 1.5 to $30.0 \mathrm{~m}^{3} \mathrm{~s}^{-1}$ in only $90 \mathrm{~min}$. This rapid increase in flow leads to significant modifications in carbon export: the DIC concentrations decrease from 350 to $145 \mathrm{umolI}^{-1}$ when the DOC concentrations increase from 87 to $338 \mu \mathrm{moll}^{-1}$, leading to an increase of the DOC/DIC ratio. This increase of DOC/DIC ratios during floods 20 has already been observed in all rivers of Basse-Terre Island (Lloret et al., 2011). This emphasized the major impact of heavy rains which modify the chemical equilibrium established into the aquifers during low water level conditions. These temporal variations in a single hydrological event illustrate the importance of an accurate sampling of the entire flood when we attempt to characterize the bio-hydro-dynamic of all forms of the
BGD

$9,7117-7163,2012$

Tropical oceanic islands carbon export

E. Lloret et al.

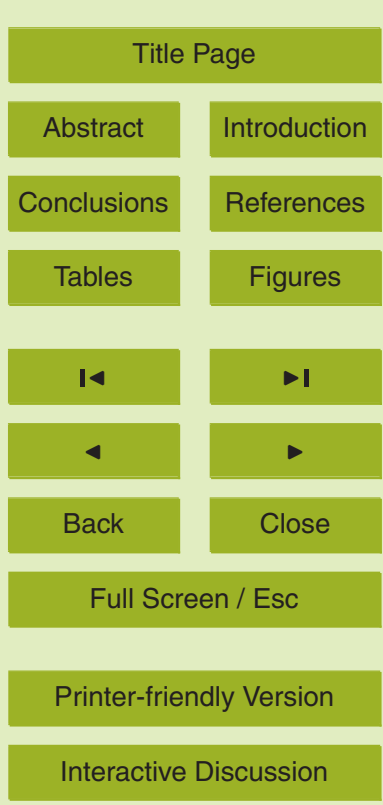




\section{Discussion}

The following discussion will first focus on the annual carbon yields for the three rivers from January 2007 to December 2010. Then the discussion will address the question of the impact of floods on carbon export and the distribution of carbon forms according to

5 the type of meteorological events (tropical storms, cyclones). Finally we will estimate the carbon mass balance at the scale of small tropical watershed and compare the carbon fluxes from small tropical rivers with those from large rivers.

\subsection{Mean annual yields of particulate and dissolved fraction for the three wa- tersheds}

10 Figure 5a, b display the concentrations of DOC, DIC, TSM, POC and PN as a function of the discharge $(Q)$ in the Capesterre river (for Bras-David and Vieux-Habitants in Fig. A2). Despite a lot of scatter, the concentration data follow linear trends on these log-log plots, suggesting power law dependencies. The concentration-discharge relationships for each element $x$ were all fitted by:

${ }_{15} C_{X}=\alpha Q^{\beta}$

where $\alpha$ and $\beta$ are proportionality constant and exponent, respectively. If we plot this power law in a graph with logarithmic scales, the power law graph is a polynomial linear law, with the following relationship: $\log \left(C_{X}\right)=\beta \log (Q)+\log (\alpha)$; where the slope is the exponent $\beta$ and the Y-intercept is the logarithm of the proportionality constant $\alpha$.

The discharges of the three studied rivers are monitored by the DEAL with a time step varying typically from one measurement every 15 min during floods to one measurement every hour at low flow. These discharge data were interpolated on a regular time step equal to $15 \mathrm{~min}$.

The instantaneous fluxes $\left(F_{\text {inst }_{x}}\right)$ of each element $x$ were then calculated with the same time resolution using the calibrated concentration-discharge relationships:

\section{BGD}

9, 7117-7163, 2012

Tropical oceanic islands carbon export

E. Lloret et al.

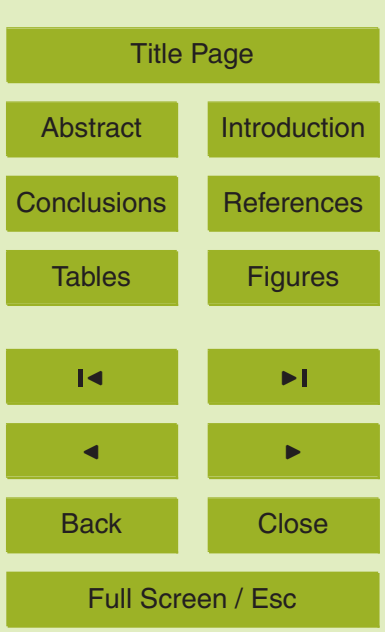

Printer-friendly Version

Interactive Discussion $F_{\text {inst }_{x}}=C_{X} Q=\alpha Q^{\beta+1}$

7129 
Integrating these curves with respect to time allowed us to compute the annual averaged fluxes $\left(F_{X}\right)$ of each element $x$ for the years 2007, 2008, 2009 and 2010:

\section{BGD}

$F_{X}=\alpha \int_{t 1}^{t 2} Q^{\beta+1} \mathrm{~d} t$

Assuming one can neglect the error on the flow rate measurement, the uncertainty on 5 the annual flux is given by:

$\Delta F_{x}=\Delta \alpha\left[\int_{t 1}^{t 2} Q^{\beta+1} \mathrm{~d} t\right]+\Delta \beta\left[\int_{t 1}^{t 2} \ln (Q) Q^{\beta+1} \mathrm{~d} t\right]=\frac{\Delta \alpha}{\alpha} F_{x}+\Delta \beta\left[\alpha \int_{t 1}^{t 2} \ln (Q) Q^{\beta+1} \mathrm{~d} t\right]$

Leading to:

$\Delta F_{X}=\frac{\Delta \alpha}{\alpha} F_{X}+\frac{\Delta \beta}{\beta+2} F_{X}+\alpha \Delta \beta\left[\frac{Q^{\beta+2}}{\beta+2} \ln Q\right] \approx \frac{\Delta \alpha}{\alpha} F_{X}+\frac{\Delta \beta}{\beta+2} F_{X}$

Note that any interruption of the discharge record on a period longer than $24 \mathrm{~h}$ was considered as a gap in the data. Gaps were not taken into account in the calculation of the annual averaged fluxes of DIC, DOC and POC. In general, the cumulated duration of gaps varies between $0 \%$ and $30 \%$ so that their influence on the calculated annual fluxes is weak. Only the Vieux-Habitants River may be problematic as the cumulated duration of gaps is $60 \%$ for 2009 and $95 \%$ in 2010 . The corresponding values of fluxes should therefore be considered with caution. The yields corresponding to the ratio of these fluxes on the surface area of the watershed are displayed in Table 1.

The DOC yields calculated for Capesterre $\left(4.9-8.6 \mathrm{tkm}^{-2} \mathrm{yr}^{-1}\right)$ are higher than yields calculated for Bras-David (2.4-4.2 $\mathrm{tkm}^{-2} \mathrm{yr}^{-1}$ ) and Vieux-Habitants (1.9$\left.2.7 \mathrm{tkm}^{-2} \mathrm{yr}^{-1}\right)$. Capesterre watershed is more exposed to rainfalls because of its

9, 7117-7163, 2012

Tropical oceanic islands carbon export

E. Lloret et al.

Title Page

Abstract

Introduction

Conclusions

References

Tables

Figures

14

$\rightarrow$

4

Back

Close

Full Screen / Esc

Printer-friendly Version

Interactive Discussion 
intensification of the erosion of soils, and thus higher yields. The lower DOC yields for Vieux-Habitants compared to Capesterre are probably due to the watershed exposure to rainfalls. Vieux-Habitants watershed located on leeward coast receives less rainfall than Capesterre. The higher DOC yields found for Bras-David compared to Vieux5 Habitants could be related to the soil thickness for Bras-David River as well as soil enrichment in organic carbon (6-9\% for the 10 first $\mathrm{cm}$ ) (Lloret, 2010). More generally, the DOC yields of the studied rivers $\left(1.9-8.6 \mathrm{tkm}^{-2} \mathrm{yr}^{-1}\right)$ are close to the yields calculated for small mountainous rivers under wet tropical (Puerto Rico rivers and Sepik River from Papua New Guinea; 1.6-11 $\mathrm{tkm}^{-2} \mathrm{yr}^{-1}$, McDowell and Asbury, 1994; Burns 10 et al., 2008) and temperate climate (New Zealand; 0.6-5.2 $\mathrm{tkm}^{-2} \mathrm{yr}^{-1}$, Carey et al., 2005). Finally, for the all 3 rivers, the DOC yields are higher in 2009 and 2010 than in 2007 and 2008, as 2009 and 2010 were the most rainy years with significant extreme floods events.

The DIC yields for Capesterre River (11.3-15.8 $\mathrm{tkm}^{-2} \mathrm{yr}^{-1}$, Table 1), are higher 15 than for Bras-David and Vieux-Habitants Rivers $\left(8.1-12.7 \mathrm{tkm}^{-2} \mathrm{yr}^{-1}\right.$, Table 1). It is likely due to the steeper slopes (>49\%) related to the young age of rock formation and high precipitations in this watershed located in the southeastern of the BasseTerre island (Lloret et al., 2011; Gaillardet et al., 2012). The DIC yields calculated for these three Guadeloupean rivers are significantly higher than the yields determined for the large rivers under wet tropical climate, like Amazon $\left(5.0 \mathrm{tkm}^{-2} \mathrm{yr}^{-1}\right)$ or Orinoco $\left(5.5 \mathrm{tkm}^{-2} \mathrm{yr}^{-1}\right)$ (Cai et al., 2008). This emphasizes that the geochemical system under investigation is mostly controlled by volcanic lithology (Louvat and Allègre, 1997; Dessert et al., 2001, 2003; Goldsmith et al., 2010; Gaillardet et al., 2012).

The POC yields calculated for Guadeloupean Rivers $\left(8.1-25.5 \mathrm{tkm}^{-2} \mathrm{yr}^{-1}\right.$, Table 1) 25 are similar to the yields calculated for small tropical mountainous rivers (Puerto Rico rivers and Sepik River from Papua New Guinea; $0.4-17 \mathrm{tkm}^{-2} \mathrm{yr}^{-1}$, McDowell and Asbury, 1994; Burns et al., 2008). The POC yields were often higher than yields determined for the large rivers under wet tropical climate, like Amazon (1.1-2.6 $\mathrm{tkm}^{-2} \mathrm{yr}^{-1}$ ) or Orinoco (1.6-5.1 $\mathrm{tkm}^{-2} \mathrm{yr}^{-1}$ ) (Beusen et al., 2005). This is likely due to the strong

BGD

$9,7117-7163,2012$

Tropical oceanic islands carbon export

E. Lloret et al.

Title Page

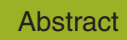

Introduction

Conclusions

Tables

References

Figures

14

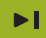

4

Back

Close

Printer-friendly Version

Interactive Discussion 
erosive power of rainfalls and the steep slopes of watersheds allowing pull up parts of soils layers enriched in organic matter and leading to important export of DOC and POC (slopes higher than 49\%) (Lloret et al., 2011). The organic carbon (DOC $+\mathrm{POC}$ ) yield calculated for Capesterre River varies between 19.4 and $41.2 \mathrm{tkm}^{-2} \mathrm{yr}^{-1}$.

5 Indeed this organic carbon yield represents more than $50 \%$ of the total carbon yield $(\mathrm{DIC}+\mathrm{DOC}+\mathrm{POC})$.

The PN yields calculated for Guadeloupean Rivers $\left(0.6-1.7 \mathrm{tkm}^{-2} \mathrm{yr}^{-1}\right.$, Table 1) are higher than yields determined for small mountainous rivers and large rivers under tropical climate $\left(0.00-0.39 \mathrm{tkm}^{-2} \mathrm{yr}^{-1}\right)$ (Lewis et al., 1999 and references therein). This is 10 probably due to the watershed slopes steeper in Guadeloupe than in other tropical regions, inducing that soil erosion is higher in Capesterre watershed than in these other tropical watersheds.

\subsection{Hydrodynamic of annual carbon export}

The instantaneous DOC versus DIC fluxes are reported on Fig. 6 for all data acquired 15 between 2007 and 2010 for the Capesterre River. DOC/DIC ratio values are illustrated on the Fig. 6 by the different straight-lines. This ratio varies between 0.1 and 2.3 and is function of the flood intensity. In this figure, extreme flood samples (EXT) are differentiated from the others (LWL + FL: low water level and floods). Three extreme floods are reported, resulting from rains related to the Dean cyclone (17 August 2007), a heavy 20 localized rainfall (13 April 2008) and the Otto cyclone (7 October 2010). During each event, a minimum of $140 \mathrm{~mm}$ of rain was recorded at the volcano summit (OVSG-IPGP data), illustrating the intensity of these events. The event intensity strongly impacts the transport and dynamic of carbon (Fig. 6). Apart from these three events, we observe that the transport of carbon is mainly inorganic, with DIC fluxes generally higher
BGD

$9,7117-7163,2012$

Tropical oceanic islands carbon export

E. Lloret et al.

Title Page

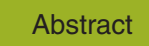

Introduction

Conclusions

Tables

References

Figures

14

$\rightarrow 1$

4

Back

Close

\section{Full Screen / Esc}

Printer-friendly Version

Interactive Discussion high DOC/DIC ratios around 2 for the Dean Cyclone samples. During extreme meteorological events, high DOC exports have typically been associated with near surface hydrologic flow paths that intersect DOC rich forest floor and superficial soil layers 
(Boyer et al., 1997; Hagedorn et al., 2000; Hornberger et al., 1994). For LWL and FL events, low DOC exports are associated to a vertical flow in soil and a short contact time with the organic rich top soil layer (Johnson et al., 2006; Lloret et al., 2011). This interpretation is supported for LWL events by $\delta^{13} \mathrm{C}$ isotopic composition of DOC as well 5 as the organic matter characteristics. Lloret et al. (2011) have shown a trend between $\delta^{13} \mathrm{C}_{\mathrm{DOC}}$ versus $1 / \mathrm{DOC}$ and between $\delta^{13} \mathrm{C}_{\mathrm{DOC}}$ versus organic matter characteristics (aromaticity, molecular weight) in Guadeloupean rivers which correspond to the mixing between two end-members. One of these end-members represents the low water level with lowest concentrations in DOC associated to largest, most aromatic, less hy${ }_{10}$ drophilic, ${ }^{13} \mathrm{C}$ less enriched and less mobile organic matter molecules. Conversely, the other end-member represents the floods with highest concentrations in DOC associated to smallest, less aromatic, most hydrophilic, ${ }^{13} \mathrm{C}$ most enriched and most mobile organic matter molecules.

The contribution of floods and extreme floods on the global carbon export, during the 15 2007-2010 period and for Capesterre River is shown in Fig. 7. The DIC fluxes occur essentially during the low water level, representing $57 \%$ of the annual flux. Organic carbon export occurs essentially during floods and extreme floods. Around $45 \%$ of the DOC is exported during floods and $25 \%$ during extreme floods. Our results show that more than $80 \%$ of the annual POC flux occurs during floods and that extreme regime explain alone $35 \%$ of this annual flux. This carbon export partitioning is observed for all years of the study, except for 2007, an unusual "dry" year mainly characterized by low water level. It emphasizes once again the great interest to monitor rivers over several years to estimate carbon exports as representative as possible in tropical context.

The most common pattern observed in many rivers in the world associates a varia25 tion in POC concentration to the discharge and the TSM concentration (Ittekot et al., 1985). Then an increase in liquid discharge associated with an increase in TSM generally causes a decrease in the percentage POC in TSM (Meybeck, 1982). This pattern has been shown to be a result of the dilution of organic matter by mineral matter and has been reported in the different tropical region like in Southeastern Asian

\section{BGD}

$9,7117-7163,2012$

Tropical oceanic islands carbon export

E. Lloret et al.

\section{Title Page}

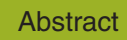

Introduction

Conclusions

Tables

References

Figures

14

$\rightarrow$

4

Back

Close

Full Screen / Esc

Printer-friendly Version

Interactive Discussion 
rivers (Ittekkot et al., 1985) and in South American rivers (Depetris and Lenardón, 1982; Hedges et al., 1986; Moreira-Turcq et al., 2003). This trend is not clearly observed for the suspended materials of Capesterre River (Fig. A1). Also the mean annual POC/TSM ratio is relatively constant over the years (ca. 0.11). The POC source 5 seems to be the same for the studied period. Indeed, the constant C/N ratio (14.7) during the studied period suggests that the $\mathrm{POC}$ in river comes more likely from the same source which corresponds to local soils with a $\mathrm{C} / \mathrm{N}=11.8$ (Lloret, 2010). The appropriate and exhaustive sampling of FL and EXT type of events is therefore a key issue to estimate correctly the DOC and POC fluxes and this is not always done in watershed 10 studies limiting the scope or the impact of the obtained results in terms of global mass balance.

The distribution of POC/DOC ratio is controlled by erosion over watershed, including climate and vegetation, geomorphology and geotectonic, and even chemical and mineral compositions as previously demonstrated by Ludwig et al. (1996b). The POC/DOC 15 ratio is sometime characteristic of the type of event, for instance Malcolm and Durum (1976) have observed in the Mississippi River a variation of POC/DOC ratios depending on the type of meteorological events, with an increasing ratio when the discharge increases. We observe the same trend in Guadeloupean Rivers, indicating an increasing of POC export higher than DOC export. The Capesterre River, with annual ratio varying between 1.35 and 1.67, does not follow the same trend observed in the large tropical rivers like Parana, Orinoco and Amazon and its major tributaries (Milliman and Meade, 1983; Richey et al., 1990; Moreira-Turcq et al., 2003), where the DOC flux is the major part of the total organic carbon flux $(\mathrm{POC} / \mathrm{DOC}<1)$. However, Wu et al. (2007) reported POC/DOC $(>1)$ in Asian rivers affected by the monsoon. An explanation would be that these rivers have extensive areas where organic matter would be generated by primary production and exported in particulate form (Burns et al., 2008) or flood-plains allowing "older geogenic" POC remobilization that will modify the POC/DOC ratio. We suppose that the high annual POC/DOC ratios (1.35-1.67) observed for Capesterre River are likely due to the mountainous topography which may lead to fast flushing of

\section{BGD}

9, 7117-7163, 2012

Tropical oceanic islands carbon export

E. Lloret et al.

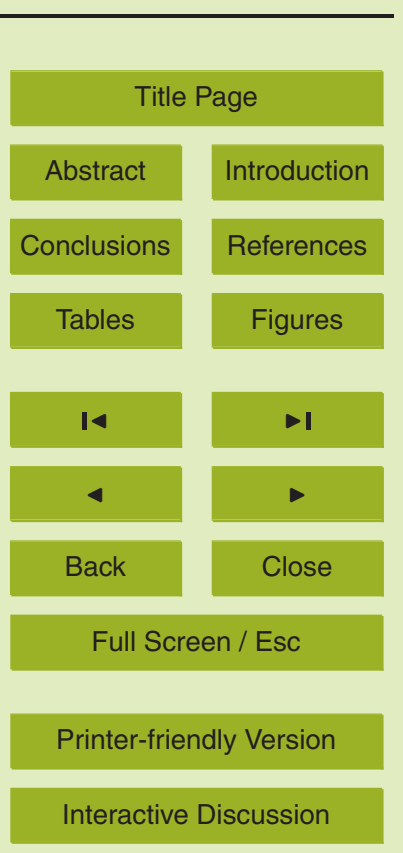


sediments (Burns et al., 2008). Unlike the large rivers, the small rivers of Guadeloupe are directly connected to the oceans and present steep slopes and no flood-plains. Erosion of soils and the strength of the event are probably the major drivers of the POC/DOC ratio observed.

\section{5.3 Carbon mass balance at the watershed scale, carbon transfer and residence} time

The carbon mass balance allows us to determine carbon dynamic at the scale of the Guadeloupean watersheds, on the light of the observations made on the Capesterre basin. To build the carbon mass balance, we need to know the different carbon inputs and outputs at the watershed scale, including the carbon inputs and outputs in soil and in river. These different inputs and outputs depend on different parameters: the carbon fluxes from rivers to ocean, the primary production and the litterfall, the carbon stock in soil, the soil carbon mass balance with soil carbon outputs and soil carbon inputs, the atmospheric inputs in river and the river degassing (Table 2; Fig. 8). These parameters are defined and calculated, or estimated with values obtained for the Capesterre River or for watersheds with same characteristics (soils, vegetation, climate, ...).

\section{Carbon mass balance $=$ carbon inputs - carbon outputs}

The carbon stock in aboveground biomass was estimated to $20000 \mathrm{tC} \mathrm{km}^{-2}$ for tropical forest (Baudin et al., 2007). The net primary production (NPP) is about $2200 \mathrm{tkm}^{-2} \mathrm{yr}^{-1}$ for the tropical rainforest (Waugh, 2002). The litterfall for the tropical rainforest is estimated between 700 and $1500 \mathrm{tkm}^{-2} \mathrm{yr}^{-1}$ (Bray and Gorham, 1964; Rodin et al., 1967; Madge, 1965; Hopkins, 1966) with an average of $1100 \mathrm{tkm}^{-2} \mathrm{yr}^{-1}$. The $\mathrm{CO}_{2}$ consumption value of tropical rainforests, which corresponds to the vegetation growth and the difference between the NPP and the litterfall, ranges between 700 and $1500 \mathrm{tkm}^{-2} \mathrm{yr}^{-1}$ with an average of $1100 \mathrm{tkm}^{-2} \mathrm{yr}^{-1}$. It is also necessary to define the carbon stock in soils. This value was estimated (between 0 and $30 \mathrm{~cm}$ depth) for andosol from

BGD

$9,7117-7163,2012$

Tropical oceanic islands carbon export

E. Lloret et al.

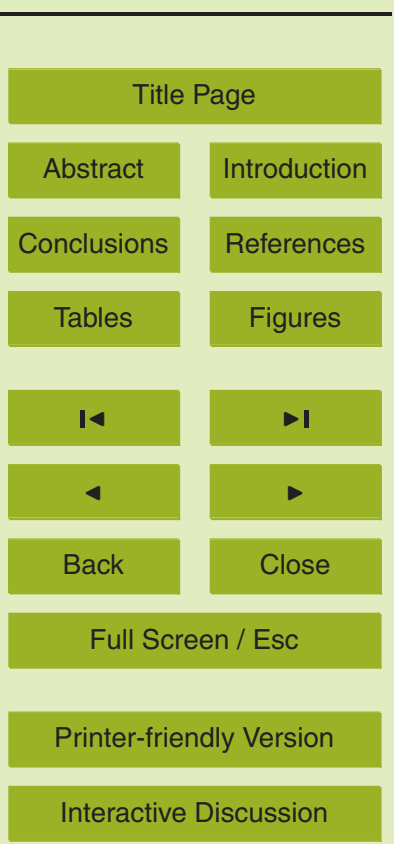

Interactive Discussion 
Martinique which are similar to Guadeloupean andosol, to be equal to $13000 \mathrm{tC} \mathrm{km}^{-2}$ between 0 and $30 \mathrm{~cm}$ of depth (Blanchart and Bernoux, 2005).

The soil carbon mass balance is defined from the soil carbon outputs and inputs. The three parameters defining the soil carbon outputs are the mineralization of organic 5 matter, the soil erosion, the groundwater contribution. The $\mathrm{CO}_{2}$ from the mineralization of organic matter is about $1022 \mathrm{tC} \mathrm{km}^{-2} \mathrm{yr}^{-1}$ for the clayey soil under tropical rainforest in Brazil (Silver et al., 2005). This value can be used for our site, because it presents the same soil characteristics, climate, temperature and rainfalls. The POC in rivers comes essentially from the soil erosion during meteorological events and its yield in the river is about $18.3 \pm 7.4 \mathrm{tC} \mathrm{km}^{-2} \mathrm{yr}^{-1}$ (average of the four studied years; Table 2). The $\mathrm{DOC}$ in rivers normally comes from groundwater during low water level, but also from soil erosion during floods. Therefore the DOC yield in the river $\left(7.4 \pm 1.7 \mathrm{tC} \mathrm{km}^{-2} \mathrm{yr}^{-1}\right.$, average of the four studied years) is the sum of the DOC yield from groundwater and the DOC yield from soil erosion. The DOC yield from groundwater ( $Y_{\mathrm{DOC}}$ groundwater) could be calculated with the following equation:

$Y_{\mathrm{DOC}}$ groundwater $=[\mathrm{DOC}]_{\mathrm{LWL}} \cdot Q_{\mathrm{LWL}}$

with $[\mathrm{DOC}]_{\mathrm{LWL}}$, the mean $\mathrm{DOC}$ concentration during low water level $\left(0.7 \mathrm{mgl}^{-1}\right.$; value for the Ravine Quiock, which is directly fed by soil solution from groundwater), and $Q_{\mathrm{LWL}}$, the mean discharge during low water level $\left(1.3 \pm 0.7 \mathrm{~m}^{3} \mathrm{~s}^{-1}\right.$; DEAL data). The 20 yield of DOC from groundwater is about $1.7 \pm 0.9 \mathrm{tC} \mathrm{km}^{-2} \mathrm{yr}^{-1}$. The DOC yield from soil erosion is the difference between the DOC yield in river and the DOC yield from groundwater and is approximately $5.7 \pm 2.6 \mathrm{tC} \mathrm{km}^{-2} \mathrm{yr}^{-1}$. The DIC yield in rivers comes essentially from the dissolution of soil and atmospheric $\mathrm{CO}_{2}$ and is about $14.1 \pm 2.0 \mathrm{tC} \mathrm{km}^{-2} \mathrm{yr}^{-1}$.

25 The parameters defining the soil carbon inputs are the litterfall, the root production and the root respiration rate. The organic carbon yield from litterfall is about $440 \mathrm{tC} \mathrm{km}^{-2} \mathrm{yr}^{-1}$ for the Guadeloupean rainforest (Lloret, 2010). The benthic decay of the litterfall in the river could be a source of organic carbon during low water periods

BGD

9, 7117-7163, 2012

Tropical oceanic islands carbon export

E. Lloret et al.

\section{Title Page}

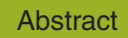

Introduction

Conclusions

Tables

References

Figures

14

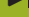

4

Back

Close

\section{Full Screen / Esc}

Printer-friendly Version

Interactive Discussion 
(Johnson et al., 2006) but cannot be estimated using the available data and is thus neglected for this study. The root production and the root respiration rate have been respectively estimated to 115 and $379 \mathrm{tC} \mathrm{km}^{-2} \mathrm{yr}^{-1}$ for a clayey soil under tropical rainforest in Brazil (Silver et al., 2005). To define the carbon mass balance at the watershed 5 scale we also need the atmospheric inputs in river and the river degassing. HeartsillScalley et al. (2007) have shown that the atmospheric inputs could be a source of DOC in rivers with precipitations and transprecipitations and are about 0.011 and $0.015 \mathrm{tC} \mathrm{km}^{-2} \mathrm{yr}^{-1}$, respectively for the Guadeloupe (Lloret, 2010). These atmospheric inputs are negligible compare to soil erosion and groundwater. The river degassing 10 yield is about $77 \mathrm{tC} \mathrm{km}^{-2} \mathrm{yr}^{-1}$ (Lloret, 2010).

The output and the input fluxes for soil represent approximately 1058 and $934 \mathrm{tkm}^{-2} \mathrm{yr}^{-1}$, respectively. Including the errors bars to these estimations, the soil carbon mass balance can be considered at steady state.

It is possible to calculate the residence times of organic carbon in soils with the 15 following formula:

Residence time of $\mathrm{OC}=\frac{\text { Stock }_{\mathrm{SOC}}}{Y_{\mathrm{DOC}}+Y_{\mathrm{POC}}}$

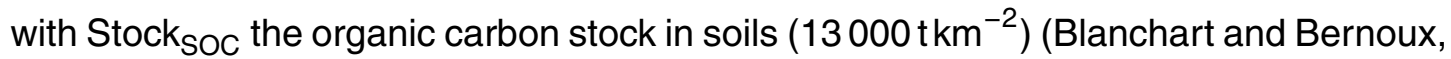
2005) and $Y_{\mathrm{DOC}}$ and $Y_{\mathrm{POC}}$ the organic carbon yields (Table 2). The SOC in the Capesterre watershed exhibits residence times similar to the ones calculated for the small tropical watershed of Puerto Rico (Rio Icacos) and the small temperate mountainous watershed of New Zealand (Waitangitaona) but shorter residence times than the ones obtained for large watersheds like the Mengong (Cameroun) and the Amazon (Brazil) (Table 2). The Waitangitaona watershed exports large amounts of modern and geological particulate organic carbon, due to its localization on an active mountain belt inducing a rapid erosion and indeed a short residence time of organic carbon in soils (Hilton et al., 2008b). For Capesterre and Rio Icacos watersheds, the short residence time (about $506 \mathrm{yr}$ and $759 \mathrm{yr}$ ) is due to the large exports of DOC and POC, related to

BGD

9, 7117-7163, 2012

Tropical oceanic islands carbon export

E. Lloret et al.

Title Page

Abstract

Introduction

Conclusions

Tables

References

Figures

14

$\rightarrow 1$

4

Back

Close

Full Screen / Esc

Printer-friendly Version

Interactive Discussion 
the lixiviation of soil surface layers and litters and the enrichment in DOC of the surface hydrologic flow paths that intersect DOC rich forest floor and superficial soil layers during meteorological events. Moreover these rivers are small and present steep slopes and no floodplains allowing temporary POC storage that could increase the residence 5 time of carbon, as observed for large river systems.

The Guadeloupean soils exhibit variable residence times, from $381 \mathrm{yr}$ in 2010 to $1000 \mathrm{yr}$ in 2007 (Table 2), depending on the overall strength of meteorological events and not only their number, since in 2007 there was 3 only extreme meteorological events for 83 floods while in 2009 and 2010 there was 12 extreme meteorological o events for 141 and 99 floods, respectively. Organic carbon exports and residence time could be under and over estimated, respectively since between 2007 and 2010 a decennial extreme flood vent like the Hugo Cyclone (17 September 1989) did not occur. During such an event, between 400 and $600 \mathrm{~mm}$ of rain was recorded at different Basse-Terre summits (La Soufrière and Merwart), and maximum discharges of 100, 15343 and $380 \mathrm{~m}^{3} \mathrm{~s}^{-1}$ were recorded for Capesterre, Bras-David and Vieux-Habitants Rivers, respectively (Morell, 1990). The associated fluxes of DOC and POC could significantly impact the over all carbon budget for the Guadeloupe island.

\subsection{Globalization}

For Guadeloupean rivers, the major part of organic carbon export occurs during the extreme meteorological events and is linked to three important parameters: the high intensity of precipitation leading to high runoff, the high slopes, and the high organic matter contents in andosols and ferralitic soils. Moreover the organic carbon export occurs essentially in particulate form. From these observations, it is interesting to compare the organic carbon export from small volcanic and tropical mountainous islands 25 with large rivers and continents.

The surface of volcanic rocks in oceanic islands and island arcs under wet tropical climate represents about $319800 \mathrm{~km}^{2}$. If we consider that average DOC and POC exports of Guadeloupean rivers is representative of DOC and POC exports by

\section{BGD}

9, 7117-7163, 2012

Tropical oceanic islands carbon export

E. Lloret et al.

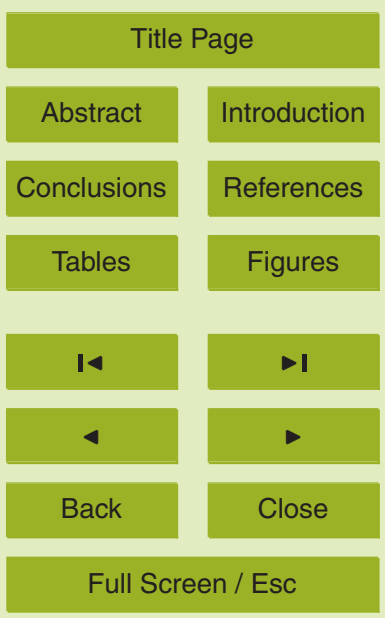

Printer-friendly Version

Interactive Discussion 
volcanic and tropical mountainous context, we can estimate an annual organic carbon exports of these islands and compare it with organic carbon exports from continental large rivers. The mean annual DOC yield for Guadeloupe Island varies between 1.9 and $8.6 \mathrm{tkm}^{-2} \mathrm{yr}^{-1}$ and the mean annual POC yield varies between 8.1 and $525.5 \mathrm{tkm}^{-2} \mathrm{yr}^{-1}$ (Table 1). The resulting global export of DOC and POC are about 0.62.8 $\mathrm{TgCyr}^{-1}$ and 2.6-8.2 $\mathrm{TgCyr}^{-1}$, respectively. This corresponds to an average DOC flux of $2.36 \mathrm{TgCyr}^{-1}(n=4)$ and it is equivalent to a fourth of Northern American rivers input to the ocean $\left(9.10 \mathrm{TgC} \mathrm{yr}^{-1}\right.$ ) or 20 times less than the south American rivers that are the biggest contributors of DOC to the world ocean $\left(43 \mathrm{TgC}^{-1}\right)$.

10 The same calculations were done for the POC and PN fluxes (Fig. 9). The average PN flux $\left(0.4 \mathrm{TgNyr}^{-1}\right)$ is in the range of particulate nitrogen flux reported for the Solimoes and the Amazon river by (Moreira-Turcq et al., 2003) and always one order of magnitude smaller than the contribution of the major subcontinent watersheds ranging from 1.69 to $4.65 \mathrm{TgNyr}^{-1}$ (Fig. 9a). The average POC export from these islands 15 (5.93 $\left.\mathrm{TgC} \mathrm{yr}^{-1}\right)$ is similar to POC export calculated for North American, the African or the European continents (Fig. 9b).

In Fig. 10, we have reported the POC/DOC ratio for each continent and for the small volcanic and tropical mountainous islands. We can observe that this ratio is very high for small volcanic and tropical mountainous islands compared to continental values.

20 This indicates that the organic matter exported by these islands is different in term of quality and reactivity from the organic matter exported by the largest rivers. A different ultimate fate for particulate and dissolved organic matter may result more from separate physical pathways than contrasting chemical compositions (Hedges et al., 1997). In the case of tropical islands organic matter, dominated by particulate organic matter 25 inputs, could settle rapidly through the marine water column and typically accumulates to suboxic depths of coastal marine sediments favoring a long term storage compared to a more rapidly degradable dissolved organic matter (Hedges et al., 1997).

According to the short residence time of organic carbon into Guadeloupean watersheds and the quantity of organic carbon exports by small tropical rivers, the carbon

\section{BGD}

9, 7117-7163, 2012

Tropical oceanic islands carbon export

E. Lloret et al.

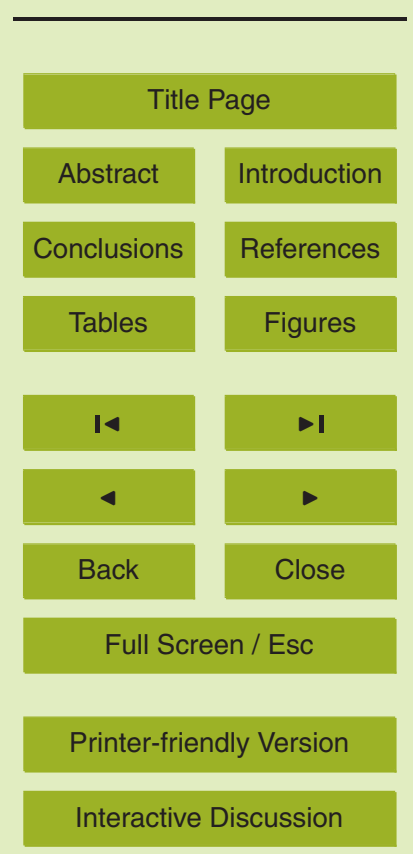

Interactive Discussion 
cycle models must take into account the organic carbon export from these small volcanic and tropical mountainous islands.

In addition the role of these islands could become more important with time as a diminishing fraction of the world's rivers remains unaffected by humans. Dams are a lead5 ing cause of disruption by leaving few major free-flowing river systems (Finer and Jenkins, 2012). They could induce significant modification downstream and upstream of the dam site for organic matter quality and total carbon flux to the ocean.

\section{Conclusions}

This study provides insight on temporal variations in particulate and dissolved organic 10 carbon and dissolved inorganic carbon in small volcanic and mountainous rivers under tropical climate.

The floods and extreme floods, which represent $10 \%$ of the annual discharge, represent between 45 and $70 \%$ of annual DOC flux, and more than $80 \%$ of the annual POC flux. The DIC fluxes occur essentially during the low water level, with about $57 \%$

15 of the annual flux. The repartition of dissolved carbon fraction between inorganic and organic form seem to depend on the hydrodynamic. Then, during low water level and floods, the dissolved carbon is essentially exported under inorganic form, while during extreme floods, the organic carbon is the dominant form.

The Guadeloupean rivers present very high DOC and POC yields. The DOC yields 20 range from 1.9 to $8.6 \mathrm{t} \mathrm{km}^{-2} \mathrm{yr}^{-1}$ and are close to the DOC yields of the large tropical rivers, like the Amazon (5.84 $\left.\mathrm{tkm}^{-2} \mathrm{yr}^{-1}\right)$ or the Orinoco $\left(4.81 \mathrm{tkm}^{-2} \mathrm{yr}^{-1}\right)$ Rivers. The POC yields vary between 8.1 and $25.5 \mathrm{tkm}^{-2} \mathrm{yr}^{-1}$ and are higher than POC yields from large tropical rivers (Amazon and Orinoco, about $1.5 \mathrm{tkm}^{-2} \mathrm{yr}^{-1}$ ). The Guadeloupean rivers are directly connected to the oceans and present steep slopes and no floodplains. Erosion of soils and strength of the event are thus probably the major drivers of the POC/DOC ratio $(>1)$ and the high POC yields observed for these rivers.

BGD

9, 7117-7163, 2012

Tropical oceanic islands carbon export

E. Lloret et al.

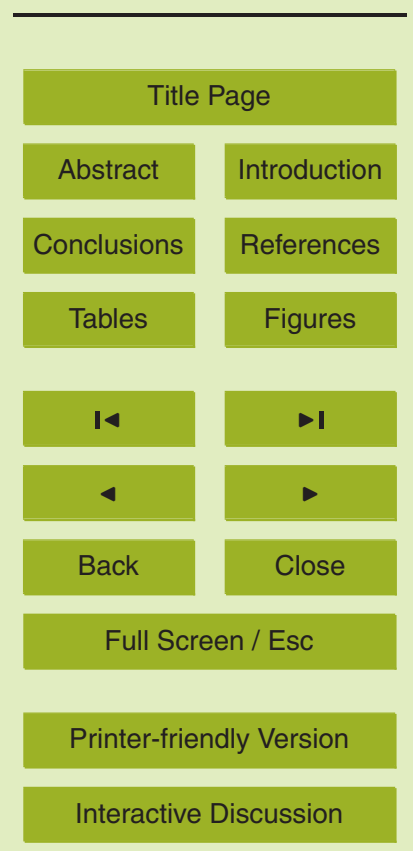


The Guadeloupean soils exhibit variable residence times, from 381 to $1000 \mathrm{yr}$, depending on the overall strength of meteorological events and not only their number.

The globalization of DOC and POC export for the all volcanic arc islands and oceanic island under tropical climate indicates that the organic carbon export from these islands 5 is non negligible in the worldwide organic carbon export and the fate of this organic matter is probably different from the one delivered by the largest rivers of the world.

Future studies on similar type of islands should be performed to validate our calculated fluxes.

\section{Supplementary material related to this article is available online at: \\ 10 http://www.biogeosciences-discuss.net/9/7117/2012/ bgd-9-7117-2012-supplement.pdf.}

Acknowledgements. This work could not be done without logistical support from the OVSG. We thank Guadeloupean DEAL for hydrologic data and Météo France Guadeloupe for rainfalls data; LGE and more precisely G. Sarazin for discussion about alkalinity and H. Lazard for her by the INSU-CNRS (PPF Obsera).

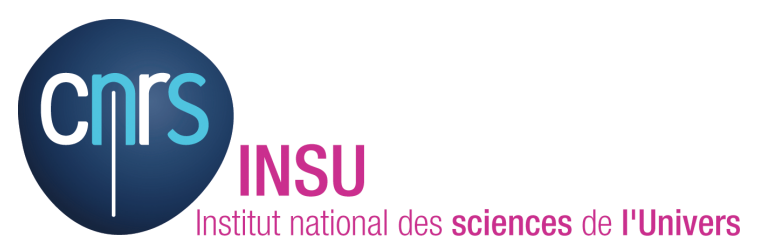

The publication of this article is financed by CNRS-INSU.

\section{BGD}

9, 7117-7163, 2012

Tropical oceanic islands carbon export

E. Lloret et al.

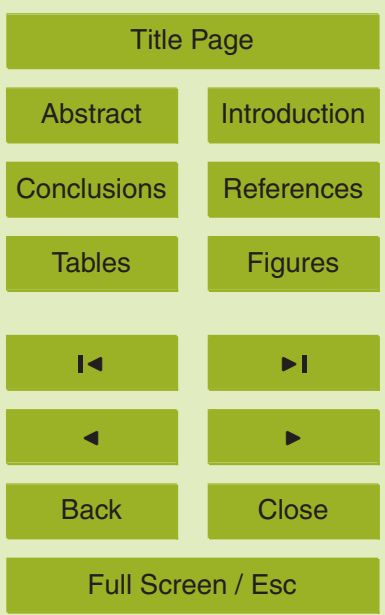

Printer-friendly Version

Interactive Discussion 


\section{References}

Aitkenhead-Peterson, J. A., McDowell, W. H., Neff, J. C., Stuart, E. G. F., and Robert, L. S.: Sources, production, and regulation of allochthonous dissolved organic matter inputs to surface waters, in: Aquatic Ecosystems, edited by: Findlay, S. E. G. and Sinsabaugh, R. L., Academic Press, Burlington, doi:10.1016/B978-012256371-3/50003-2, pp. 25-70, 2003.

Aufdenkampe, A. K., Mayorga, E., Hedges, J. I., Llerena, C., Quay, P. D., Gudeman, J., Krusche, A. V., and Richey, J. E.: Organic matter in the Peruvian headwaters of the Amazon: compositional evolution from the Andes to the lowland Amazon mainstem, Org. Geochem., 38, 337-364, doi:10.1016/j.orggeochem.2006.06.003, 2007.

Baudin, F., Tribovillard, N., and Trichet, J.: Géologie de la Matière Organique, Société Géologique de France, Vuibert, Paris, 2007.

Benedetti, M. F., Van Riemsdijk, W. H., and Koopal, L. K.: Humic substances considered as a heterogeneous Donnan Gel Phase, Environ. Sci. Technol., 30, 1805-1813, doi:10.1021/es950012y, 1996.

15 Benedetti, M. F., Dia, A., Riotte, J., Chabaux, F., Gérard, M., Boulègue, J., Fritz, B., Chauvel, C., Bulourde, M., Déruelle, B., and Ildefonse, P.: Chemical weathering of basaltic lava flows undergoing extreme climatic conditions: the water geochemistry record, Chem. Geol., 201, 1-17, doi:10.1016/S0009-2541(03)00231-6, 2003.

Berner, R. A.: Biogeochemical cycles of carbon and sulfur and their effect on atmospheric oxygen over Phanerozoic time, Palaeogeogr. Palaeocl., 73, 97-122, doi:10.1016/00310182(89)90186-7, 1989.

Beusen, A. H. W., Dekkers, A. L. M., Bouwman, A. F., Ludwig, W., and Harrison, J.: Estimation of global river transport of sediments and associated particulate $\mathrm{C}, \mathrm{N}$, and $\mathrm{P}$, Global Biogeochem. Cy., 19, GB4S05, doi:10.1029/2005GB002453, 2005.

25 Bianchi, T. S., Galler, J. J., and Allison, M. A.: Hydrodynamic sorting and transport of terrestrially derived organic carbon in sediments of the Mississippi and Atchafalaya Rivers, Estuar. Coast. Shelf S., 73, 211-222, doi:10.1016/j.ecss.2007.01.004, 2007.

Blanchart, E., and Bernoux, M.: Déterminants des stocks de carbone des sols des Petites Antilles (Martinique, Guadeloupe). Alternatives de séquestration du carbone et spatialisation du Développement Durable, Montpellier, 2005.

BGD

9, 7117-7163, 2012

\section{Tropical oceanic islands carbon export}

E. Lloret et al.

\section{Title Page}

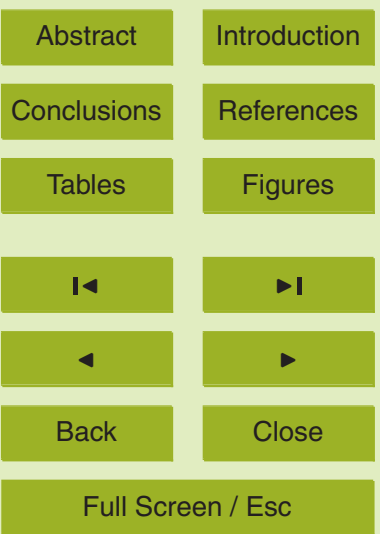

Printer-friendly Version

Interactive Discussion 
Boeglin, J. L., Probst, J. L., Ndam Ngoupayou, J., Nyeck, B., Etcheber, H., Mortatti, J., and Braun, J. J.: Chapter 18 - Soil carbon stock and river carbon fluxes in humid tropical environments: the Nyong River basin (South Cameroun), in: Soil Erosion and Carbon Dynamics, edited by: Feller, C., Roose, E. J., Stewart, B. A., Barthés, B., and Lal, R., CRC Press, Boca Raton, FL, doi:10.1201/9780203491935.ch18, pp. 275-287, 2005.

Bouchez, J., Beyssac, O., Galy, V., Gaillardet, J., France-Lanord, C., Maurice, L., and MoreiraTurcq, P.: Oxidation of petrogenic organic carbon in the Amazon floodplain as a source of atmospheric CO2, Geology, 38, 255-258, 2010.

Boyer, E. W., Hornberger, G. M., Bencala, K. E., and Mcknight, D. M.: Response characteristics of DOC flushing in an alpine catchment, Hydrol. Process., 11, 1635-1647, doi:10.1002/(SICI)1099-1085(19971015)11:12;1635::AID-HYP494¿3.0.CO;2-H, 1997.

Bray, J. and Gorham, E.,: Litter production of forests of the world, Adv. Ecol. Res., 2, 101-157, doi:10.1016/S0065-2504(08)60331-1, 1964.

Burdige, D. J.: Burial of terrestrial organic matter in marine sediments: a reassessment, Global Biogeochem. Cy., 19, 1-7, doi:10.1029/2004GB002368, 2005.

Burns, K. A., Brunskill, G., Brinkman, D., and Zagorskis, I.: Organic carbon and nutrient fluxes to the coastal zone from the Sepik River outflow, Cont. Shelf Res., 28, 283-301, doi:10.1016/j.csr.2007.08.004, 2008.

Buss, H. L., White, A. F., Dessert, C., Gaillardet, J., Blum, A. E., and Sak, P. B.: Depth profiles in a tropical volcanic critical zone observatory: Basse-Terre, Guadeloupe, in: Proceedings of the 13th International conference on water-Rock Interaction, edited by: Torres-Alvarado, I. S. and Birkkle, P., Taylor \& Francis Group, London, UK, doi:10.1201/b10556-6, pp. 245-248, 2010.

Cai, W.-J., Guo, X., Chen, C.-T. A., Dai, M., Zhang, L., Zhai, W., Lohrenz, S. E., Yin, K., Harrison, P. J., and Wang, Y.: A comparative overview of weathering intensity and $\mathrm{HCO}_{3}^{-}$flux in the world's major rivers with emphasis on the Changjiang, Huanghe, Zhujiang (Pearl) and Mississippi Rivers, Cont. Shelf Res., 28, 1538-1549, doi:10.1016/j.csr.2007.10.014, 2008.

Calmels, D., Galy, A., Hovius, N., Bickle, M., West, A. J., Chen, M.-C., and Chapman, H.: Contribution of deep groundwater to the weathering budget in a rapidly eroding mountain belt,

Carey, A. E., Gardner, C. B., Goldshmith, S. T., Lyons, W. B., and Hicks, D. M.: Organic carbon yields from small, mountainous rivers, New Zealand, Geophys. Res. Lett., 32, L15404, doi:10.1029/2005GL023159, 2005.

\section{BGD}

9, 7117-7163, 2012

Tropical oceanic islands carbon export

E. Lloret et al.

\section{Title Page}

\section{Abstract}

Introduction

Conclusions References

Tables Figures

14 $\rightarrow$

4

Back

Close

Full Screen / Esc

Printer-friendly Version

Interactive Discussion 
Cattan, P., Voltz, M., Cabidoche, Y.-M., Lacas, J.-G., and Sansoulet, J.: Spatial and temporal variations in percolation fluxes in a tropical andosol influenced by banana cropping patterns, J. Hydrol., 355, 157-169, doi:10.1016/j.jhydrol.2006.11.009, 2007.

Colmet-Daage, F. and Lagache, P.: Caractéristiques de quelques groups de sols derives de roches volcaniques aux Antilles françaises, Cah. ORSTOM Sér. Pédol., 3, 91-121, 1965.

Colmet-Daage, F. and Bernard, Z.: Contribution à l'Atlas des départements d'Outre-mer: Guadeloupe. Carte des sols de la Guadeloupe, Grande-Terre, Marie-Galante. Carte des pentes et du modelé de la Guadeloupe, Grande-Terre, Marie-Galante, ORSTOM Antilles, 1979.

10 Coomes, D. A., Allen, R. B., Scott, N. A., Goulding, C., and Beets, P.: Designing systems to monitor carbon stocks in forests and shrublands, Forest Ecol. Manag., 164, 89-108, doi:10.1016/S0378-1127(01)00592-8, 2002.

Dawson, J. J. C., Soulsby, C., Tetzlaff, D., Hrachowitz, M., Dunn, S. M., and Malcolm, I. A.: Influence of hydrology and seasonality on DOC exports from three contrasting upland catchments, Biogeochemistry, 90, 93-113, doi:10.1007/s10533-008-9234-3, 2008.

Degens, E. T. and Ittekkot, V.: Particulate organic carbon: an overview, in: Transport of Carbon and Minerals in Major World Rivers, edited by: Degens, E. T., Kempe, S., and Herrera, R., SCOPE/UNEP Sonderband 58, Mitteilungen des Geologisch-Paläontologischen Instituts der Universität Hamburg, pp. 7-27, 1985.

Depetris, P. J. and Lenardón, A. M.: Particulate and dissolved phases in the Parana River, in: Transport of Carbon and Minerals in Major World Rivers, Part I, edited by: Degens, E. T., SCOPE/UNEP Sonderband 52, Mitteilungen des Geologisch-Paläontologischen Instituts der Universität Hamburg, 385-395, 1982.

Dessert, C., Dupré, B., François, L. M., Schott, J., Gaillardet, J., Chakrapani, G., and Bajpai, S.: Erosion of Deccan Traps determined by river geochemistry: impact on the global climate and the ${ }^{87} \mathrm{Sr} /{ }^{86} \mathrm{Sr}$ ratio of seawater, Earth Planet. Sc. Lett., 188, 459-474, doi:10.1016/S0012821X(01)00317-X, 2001.

Dessert, C., Dupré, B., Gaillardet, J., François, L. M., and Allègre, C. J.: Basalt weathering laws and the impact of basalt weathering on the global carbon cycle, Chem. Geol., 202, 257-273,

30 doi:10.1016/j.chemgeo.2002.10.001, 2003.

Dessert, C., Gaillardet, J., Dupré, B., Schott, J., and Pokrovsky, O. S.: Fluxes of high- versus low-temperature water-rock interactions in aerial volcanic areas: exam-
BGD

9, 7117-7163, 2012

\section{Tropical oceanic islands carbon export}

E. Lloret et al.

\section{Title Page}

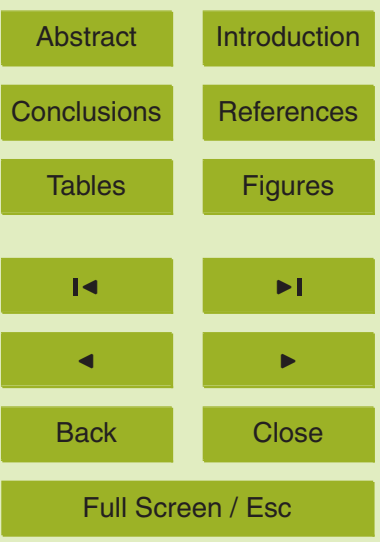

Printer-friendly Version

Interactive Discussion 
ple from the Kamchatka Peninsula, Russia, Geochim. Cosmochim. Ac., 73, 148-169, doi:10.1016/j.gca.2008.09.012, 2009.

Dittmar, T. and Kattner, G.: The biogeochemistry of the river and shelf ecosystem of the Arctic Ocean: a review, Mar. Chem., 83, 103-120, doi:10.1016/S0304-4203(03)00105-1, 2003.

5 Duan, S., Bianchi, T. S., and Sampere, T. P.: Temporal variability in the composition and abundance of terrestrially-derived dissolved organic matter in the lower Mississippi and Pearl Rivers, Mar. Chem., 103, 172-184, doi:10.1016/j.marchem.2006.07.003, 2007.

Duchauffour, P.: Introduction à la science du sol. Sol, végétation, environnement, Dunod, Paris, 2001.

10 Finer, M. and Jenkins, C. N.: Proliferation of hydroelectric dams in the Andean Amazon and implications for Andes-Amazon connectivity, Plos ONE, 7, e35126, doi:10.1371/journal.pone.0035126, 2012.

Gaillardet, J., Rad, S., Rivé, K., Louvat, P., Gorge, C., Allègre, C. J., and Lajeunesse, E.: Orography-driven chemical denudation in the Lesser Antilles: evidence for a new feed-back mechanism stabilizing atmospheric $\mathrm{CO}_{2}$, Am. J. Sci., 311, 851-894, doi:102475/10.201102, 2012.

Galy, V., France-Lanord, C., Beyssac, O., Faure, P., Kudrass, H., and Palhol, F.: Efficient organic carbon burial in the Bengal fan sustained by the Himalayan erosional system, Nature, 450, 407-411, doi:10.1038/nature06273, 2007.

20 Galy, V., France-Lanord, C., and Lartiges, B.: Loading and fate of particulate organic carbon from the Himalaya to Ganga-Brahmaputra delta, Geochim. Cosmochim. Ac., 72, 1767-1787, doi:10.1016/j.gca.2008.01.027, 2008.

Gebhardt, A. C., Gaye-Haake, B., Unger, D., Lahajnar, N., and Ittekot, V.: Recent particulate organic carbon and total suspended matter fluxes from the $\mathrm{Ob}$ and Yenisei Rivers into the Kara Sea (Siberia), Mar. Geol., 207, 225-245, doi:10.1016/j.margeo.2004.03.010, 2004.

Goldsmith, S. T., Carey, A. E., Lyons, W. B., Kao, S.-J., Lee, T.-Y., and Chen, J.: Extreme storm events, landscape denudation, and carbon sequestration: typhoon Mindulle, Choshui River, Taiwan, Geology, 36, 483-486, doi:10.1130/G24624A.1, 2008.

Goldsmith, S. T., Carey, A. E., Johnson, B. M., Welch, S. A., Lyons, W. B., McDowell, W. H., and Pigott, J. S.: Stream geochemistry, chemical weathering and $\mathrm{CO}_{2}$ consumption potential of andesitic terrains, Dominica, Lesser Antilles, Geochim. Cosmochim. Ac., 74, 85-103, doi:10.1016/j.gca.2009.10.009, 2010.

BGD

$9,7117-7163,2012$

Tropical oceanic islands carbon export

E. Lloret et al.

\section{Title Page}

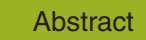

Introduction

Conclusions

References

Tables

Figures

14

4

Back

Close

Full Screen / Esc

Printer-friendly Version

Interactive Discussion 
Gordon, E. S. and Goñi, M. A.: Controls on the distribution and accumulation of terrigenous organic matter in sediments from the Mississippi and Atchafalaya river margin, Mar. Chem., 92, 331-352, doi:10.1016/j.marchem.2004.06.035, 2004.

Gregory, P. J., Ingram, J. S. I., Campbell, B., Goudriaan, J., Hunt, L. A., Landsberg, J. J., Linder, S., Stafford Smith, M., Sutherst, R. W., and Valentin, C.: Managed production systems, in: The Terrestrial Biosphere and Global Change. Implications for Natural and Managed Ecosystems. Synthesis volume, edited by: Walker, B., Steffen, W. L., Canadell, J., and Ingram, J. S. I., Cambridge University Press, Cambridge, pp. 229-270, 1999.

Hagedorn, F., Schleppi, P., Waldner, P., and Fluhler, H.: Export of dissolved organic carbon and nitrogen from Gleysol dominated catchments - the significance of water flow paths, Biogeochemistry, 50, 137-161, doi:10.1023/A:1006398105953, 2000.

Heartsill-Scalley, T., Scatena, F. N., Estrada, C., McDowell, W. H., and Lugo, A. E.: Disturbance and long-term patterns of rainfall and throughfall nutrient fluxes in a subtropical wet forest in Puerto Rico, J. Hydrol., 333, 472-485, doi:10.1016/j.jhydrol.2006.09.019, 2007.

Hedges, J. I. and Keil, R. G.: Sedimentary organic matter preservation: an assessment and speculative synthesis, Mar. Chem., 49, 137-139, doi:10.1016/0304-4203(95)00013-H, 1995.

Hedges, J. I., Clark, W. A., Quay, P. D., Richey, J. E., Devol, A., and Santos, U.: Composition and fluxes of particulate organic material in the Amazon River, Limnol. Oceanogr., 31, 717-738, doi:10.4319/lo.1986.31.4.0717, 1986.

Hedges, J. I., Cowie, G. L., Richey, J. E., Quay, P. D., Benner, R., Strom, M., and Forsberg, B. R.: Origins and processing of organic matter in the Amazon River as indicated by carbohydrates and amino acids, Limnol. Oceanogr., 39, 743-761, doi:10.4319/lo.1994.39.4.0743, 1994.

Hedges, J. I., Keil, R. G., and Berner, R.: What happens to terrestrial organic matter in the Ocean?, Org. Geochem., 27, 195-212, doi:10.1016/S0146-6380(97)00066-1, 1997.

Hilton, R. G., Galy, A., Hovius, N., Chen, M. C., Horng, M. J., and Chen, H. Y.: Tropicalcyclone-driven erosion of the terrestrial biosphere from mountains, Nat. Geosci., 1, 759-762, doi:10.1038.ngeo333, 2008a.

Hilton, R. G., Galy, A., and Hovius, N.: Riverine particulate organic carbon from an active mountain belt: importance of landslides, Global Biogeochem. Cy., 22, 1-12, doi:10.1029/2006GB002905, 2008b.

Holmes, R. M., McClelland, J. W., Peterson, B. J., Shiklomanov, I. A., Shiklomanov, A. I., Zhulidov, A. V., Gordeev, V. V., and Bobrovitskaya, N. N.: A circumpolar perspective
BGD

9, 7117-7163, 2012

Tropical oceanic

islands carbon export

E. Lloret et al.

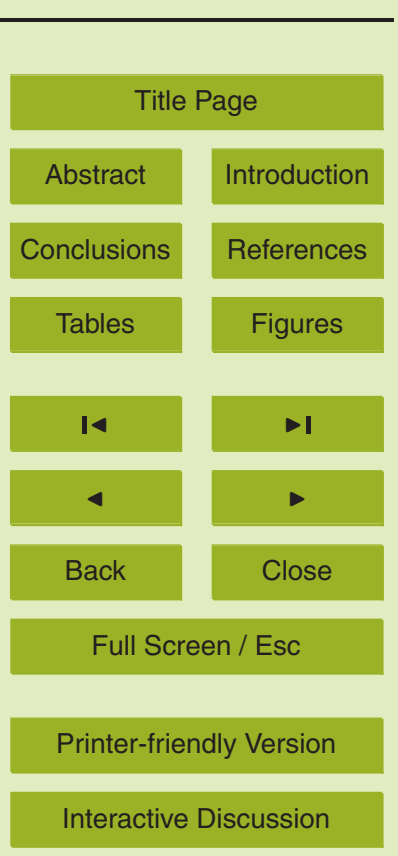


on fluvial sediment flux to the Arctic Ocean, Global Biogeochem. Cy., 16, 1849-1862, doi:10.1029/2001GB001849, 2002.

Hopkins, B.: Vegetation of the Olokemeji forest reserve, Nigeria. IV. The litter and the soil, with special reference to their seasonal changes, J. Ecol., 54, 687-703, 1966.

5 Hornberger, G. M., Bencala, K. E., and Mcknight, D. M.: Hydrological controls on dissolved organic carbon during snowmelt in the Snake River near Montezuma, Colorado, Biogeochemistry, 25, 147-165, doi:10.1007/BF00024390, 1994.

Ittekkot, V., Safiullah, S., Mycke, B., and Seifert, R.: Seasonal variability and geochemical significance of organic matter in the River Ganges, Bangladesh, Nature, 317, 800-802, doi:10.1038/317800a0, 1985.

Johnson, M. S., Lehmann, J., Couto, E. G., Novaes, J. P., and Riha, S. J.: DOC and DIC in flowpaths of Amazonian headwater catchments with hydrologically contrasting soils, Biogeochemistry, 81, 45-57, doi:10.1007/s10533-006-9029-3, 2006.

Jouvin, D., Louvat, P., Juillot, F., Marechal, C. N., and Benedetti, M. F.: Zinc isotopic fractionation: why organic matters, Environ. Sci. Technol., 43, 5747-5754, doi:10.1021/es803012e, 2009.

Kao, S. J. and Liu, K. K.: Particulate organic carbon export from a subtropical mountainous river (Lanyang Hsi) in Taiwan, Limnol. Oceanogr., 41, 1749-1757, doi:10.4319/lo.1996.41.8.1749, 1996.

20 Lal, R.: Soil erosion and the global carbon budget, Environ. Int., 29, 437-450, doi:10.1016/S0160-4120(02)00192-7, 2003.

Lal, R.: Soil carbon sequestration impacts on global climate change and food security, Science, 304, 1623-1627, doi:10.1126/science.1097396, 2004.

Lewis Jr., W. M., Melack, J. M., McDowell, W. H., McClain, M., and Richey, J. E.: Nitrogen yields from undisturbed watersheds in the Americas, Biogeochemistry, 46, 149-162, doi:10.1007/BF01007577, 1999.

Lloret, E.: Dynamique du carbone dans des petits bassins versants tropicaux, exemple de la Guadeloupe, PhD Thesis, University of Paris-7, Paris, France, 2010.

Lloret, E., Dessert, C., Gaillardet, J., Albéric, P., Crispi, O., Chaduteau, C., and Benedetti, M. F.: 30 Comparison of dissolved inorganic and organic carbon yields and fluxes in the watersheds of tropical volcanic islands, examples from Guadeloupe (French West Indies), Chem. Geol., 280, 65-78, doi:10.1016/j.chemgeo.2010.10.016, 2011.

BGD

9, 7117-7163, 2012

Tropical oceanic islands carbon export

E. Lloret et al.

Title Page

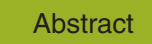

Introduction

Conclusions

References

Tables

Figures

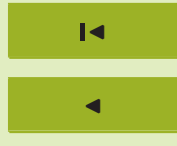

$\rightarrow 1$

Back

Close

Full Screen / Esc

Printer-friendly Version

Interactive Discussion 
Louvat, P.: Etude géochimique de l'érosion fluviale d'îles volcaniques à l'aide des bilans d'éléments majeurs et traces, PhD Thesis, University of Paris-7, Paris, France, 1997.

Louvat, P. and Allègre, C. J.: Present denudation rates at Réunion Island determined by river geochemistry: basalt weathering and mass budget between chemical and mechanical erosions, Geochim. Cosmochim. Ac., 61, 3645-3669, doi:10.1016/S0016-7037(97)00180-4, 1997.

Ludwig, W., Amiotte-Suchet, P., and Probst, J. L.: River discharges of carbon to the world's oceans: determining local inputs of alkalinity and of dissolved and particulate organic carbon, C.R. Acad. Sci. II A, 323, 1007-1014, 1996a.

10 Ludwig, W., Probst, J. L., and Kempe, S.: Predicting the oceanic input of organic carbon by continental erosion, Global Biogeochem. Cy., 10, 23-41, doi:10.1029/95GB02925, 1996b.

Lyons, W. B., Nezat, C. A., Carey, A. E., and Hicks, D. M.: Organic carbon fluxes to the ocean from high-standing islands, Geology, 30, 443-446, doi:10.1130/?00917613(2002)030<0443:OCFTTO>?2.0.CO;2, 2002.

Madge, D. S.: Leaf fall and litter disappearance in a tropical forest, Pedobiologia, 5, 273-288, 1965.

Malcolm, R. A. and Durum, W. H.: Organic carbon and nitrogen concentrations and annual organic carbon load of six selected rivers of the United States, Geological Survey WaterSupply Paper, Government Printing Office, Washington, 1976.

20 McDowell, W. H. and Asbury, C. E.: Export of carbon, nitrogen, and major ions from three tropical montane watersheds, Limnol. Oceanogr., 39, 111-125, doi:10.4319/lo.1994.39.1.0111, 1994.

Meybeck, A. and Ragu, M.: River discharges to the oceans. An assessment of suspended solids, major ions and nutrient, Environment Information and Assessment Report, UNEP, 25 Nairobi, 1996.

Meybeck, M.: Carbon, nitrogen, and phosphorous transport by world rivers, Am. J. Sci., 282, 401-450, doi:10.2475/ajs.282.4.401, 1982.

Milliman, J. D. and Meade, R.: Worldwide delivery of river sediment to the oceans, J. Geol., 91, 1-21, doi:10.1086/628741, 1983.

30 Milliman, J. D. and Syvitski, P. M.: Geomorphic/tectonic control of sediment discharge to the ocean: the importance of small mountainous rivers, J. Geol., 100, 525-544, doi:10.1086/629606, 1992.

\section{BGD}

9, 7117-7163, 2012

Tropical oceanic islands carbon export

E. Lloret et al.

\section{Title Page}

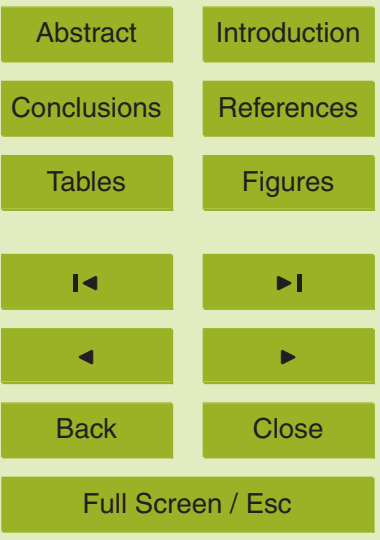

Printer-friendly Version

Interactive Discussion 
Moreira-Turcq, P., Seyler, P., Guyot, J. L., and Etcheber, H.: Exportation of organic carbon from the Amazon River and its main tributaries, Hydrol. Process., 17, 1329-1344, doi:10.1002/hyp.1287, 2003.

Morell, M.: Ouragans, crues, et inondations en Guadeloupe, paper presented at International 5 symposium on Les risques naturels et technologiques, dans le bassin Caribéen, Fort de France, Martinique, 22-26 May, 1990.

Mounier, S., Benedetti, M. F., Benaïm, J. Y., and Boulègue, J.: Organic matter size dynamics in the Amazon River, in: The Ecohydrology of South American Rivers and Wetlands, edited by: McClain, M. E., IAHS Special publication no. 6, International Association of Hydrological

10 Sciences, Wallington, Oxfordshire, UK, pp. 25-35, 2002.

Nelson, P. N., Baldock, J. A., and Oades, J. M.: Concentration and composition of dissolved organic carbon in streams in relation to catchment soil properties, Biogeochemistry, 19, 2750, doi:10.1007/BF00000573, 1993.

Oades, J. M.: The retention of organic matter in soils, Biogeochemistry, 5, 35-70, 15 doi:10.1007/BF02180317, 1988.

Plaisir, J., Démonio, W., and Claudin, J.: Atlas du Parc National de Guadeloupe, Ministère de l'Ecologie et du Développement Durable, Guadeloupe, 2003.

Rachold, V., Eicken, H., Gordeev, V. V., Grigoriev, M. N., Hubberten, H.-W., Lisitzin, A. P., Shevchenko, V. P., and Schirrmeister, L.: Modern terrigenous organic carbon input to the Arctic Ocean, in: The Organic Carbon Cycle in the Arctic Ocean, edited by: Stein, R. and Macdonald, R. W., Springer, New York, pp. 33-56, 2004.

Rad, S. D., Allègre, C. J., and Louvat, P.: Hidden erosion on volcanic islands, Earth Planet. Sc. Lett., 262, 109-124, doi:10.1016/j.epsl.2007.07.019, 2007.

Raymond, P. A., McClelland, J. W., Holmes, R. M., Zhulidov, A. V., Mull, K., Peterson, B. J., Striegl, R. G., Aiken, G. R., and Gurtovaya, T. Y.: Flux and age of dissolved organic carbon exported to the Arctic Ocean: a carbon isotopic study of the five largest Arctic rivers, Global Biogeochem. Cy., 21, 1-9, doi:10.1029/2007GB002934, 2007.

Richey, J. E., Hedges, J. I., Devol, A. H., Quay, P. D., Victoria, R., Martinelli, L., and Forsberg, B. R.: Biogeochemistry of carbon in the Amazon River, Limnol. Oceanogr., 35, 352371, doi:10.4319/lo.1990.35.2.0352, 1990.

Rodin, L. E., Basilevitch, N. I., and Fogg, G.: Production and Mineral Cycling in Terrestrial Vegetation, Oliver and Boyd, Edinburg, London, 1967.
BGD

9, 7117-7163, 2012

Tropical oceanic islands carbon export

E. Lloret et al.

Title Page

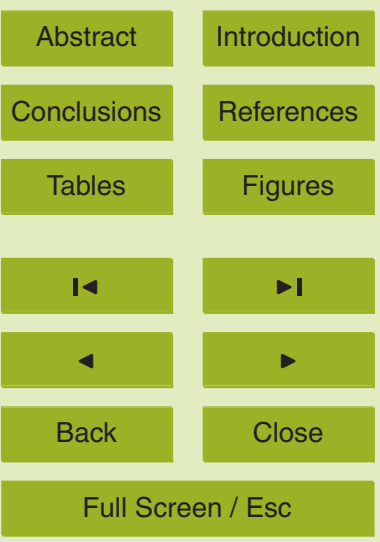

Printer-friendly Version

Interactive Discussion 
Romankevich, E. A. and Artemyev, V. E.: Input of organic carbon into seas and oceans bordering the territory of the Soviet Union, in: Transport of Carbon and Minerals in Major World Rivers, edited by: Degens, E. T., Kempe, S., and Herrera, R., SCOPE/UNEP Sonderband 58, Mitteilungen des Geologisch-Paläontologischen Instituts der Universität Hamburg, 459-469, 1985.

Rousteau, A.: Structures, flores, dynamiques: réponses des forêts pluviales des Petites Antilles aux milieux montagnards, in: Phytogéographie Tropicale: Réalités et Perspectives, edited by: Guillaumet, J. L., Belin, M., and Puig, H., ORSTOM, Paris, pp. 307-321, 1996.

Rousteau, A., Portecop, J., and Rollet, B.: Carte écologique de la Guadeloupe, Université Antilles Guyane, ONF, Conseil Général, Parc National de la Guadeloupe, Guadeloupe, 1994.

Saffache, P., Marc, J.-V., and Huyghes-Belrose, V.: Les cyclones en Guadeloupe: quatre siècles cataclysmiques, Ibis Rouge, Martinique, 2003.

Sak, P. B., Navarre-Stichler, A. K., Miller, C. E., Daniel, C. C., Gaillardet, J., Buss, H. L., Lebedeva, M. I., and Brantley, S. L.: Controls on rind thickness on basaltic andesite clasts weathering in Guadeloupe, Chem. Geol., 276, 129-143, doi:10.1016/j.chemgeo.2010.05.002, 2010.

Samper, A., Quidelleur, X., Lahitte, P., and Mollex, D.: Timing of effusive volcanism and collapse events within an oceanic arc island: Basse-Terre, Guadeloupe archipelago (Lesser Antilles Arc), Earth Planet. Sc. Lett., 258, 175-191, doi:10.1016/j.epsl.2007.03.030, 2007.

Schlesinger, W. H.: Carbon balance in terrestrial detritus, Annu. Rev. Ecol. Evol. S., 8, 51-81, doi:10.1146/annurev.es.08.110177.000411, 1977.

Schlünz, B. and Schneider, R. R.: Transport of terrestrial organic carbon to the oceans by rivers: re-estimating flux- and burial rates, Int. J. Earth Sci., 88, 599-606, doi:10.1007/s005310050290, 2000.

Sugimura, Y. and Suzuki, Y.: A high-temperature catalytic oxidation method for the determination of non-volatile dissolved organic carbon in seawater by direct injection of a liquid sample, Mar. Chem., 24, 105-131, doi:10.1016/0304-4203(88)90043-6, 1988.

Silver, W. L., Thompson, A. W., McGroddy, M. E., Varner, R. K., Dias, D. J., Silva, H., Crill, P. M., and Keller, M.: Fine root dynamics and trace gas fluxes in two lowland tropical forest soils, GCB, 11, 290-306, doi:10.1111/j.1365-2486.2005.00903.x, 2005.

30 Walling, D. E.: The sediment delivery problem, J. Hydrol., 65, 209-237, doi:10.1016/00221694(83)90217-2, 1983.

Waterloo, M. J., Oliveira, S. M., Drucker, D. P., Nobre, A. D., Cuartas, L. A., Hodnett, M. G., Langedijk, I., Jans, W. W. P., Tomasella, J., de Araujo, A. C., Pimentel, T. P., and
BGD

9, 7117-7163, 2012

Tropical oceanic islands carbon export

E. Lloret et al.

Title Page

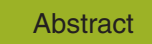

Introduction

Conclusions

Tables

References

Figures

14

$\rightarrow$ I

4

Back

Close

Full Screen / Esc

Printer-friendly Version

Interactive Discussion 
Estrada, J. C. M.: Export of organic carbon in run-off from an Amazonian rainforest blackwater catchment, Hydrol. Process., 20, 2581-2597, doi:10.1002/hyp.6217, 2006.

Waugh, D.: Geography: an Integrated Approach, Nelson Thornes, Cheltenham, UK, 2002.

Whitehead, D., Hall, G. M. J., Walcroft, A. S., Brown, K. J., Landsberg, J. J., Tissue, D. T., 5 Turnbull, M. H., Griffin, K. L., Schuster, W. S. F., Carswell, F. E., Trotter, C. M., James, I. L., and Norton, D. A.: Analysis of the growth of rimu (Dacrydium cupressinum) in South Westland, New Zealand, using process-based simulation models, Int. J. Biometeorol., 46, 66-75, doi:10.1007/s00484-001-0122-y, 2002.

Wu, Y., Zhang, J., Liu, S. M., Zhang, Z. F., Yao, Q. Z., Hong, G. H., and Cooper, L.: Sources and repartition of carbon within the Yangtze River system, Estuar. Coast. Shelf S., 71, 13-25, doi:10.1016/j.ecss.2006.08.016, 2007.

Zahibo, N., Pelinovsky, E., Talipova, T., Rabinovich, A., Kurikin, A., and Nikolkina, I.: Statistical analysis of cyclone hazard for Guadeloupe, Lesser Antilles, Atmos. Res., 84, 13-29, doi:10.1016/j.atmosres.2006.03.008, 2007.

\section{BGD}

9, 7117-7163, 2012

\section{Tropical oceanic islands carbon export}

E. Lloret et al.

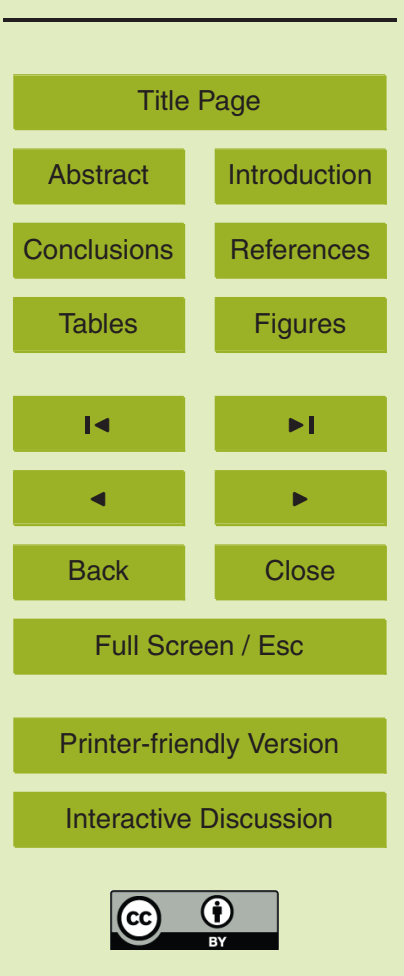


BGD

9, 7117-7163, 2012

Tropical oceanic

islands carbon export

E. Lloret et al.

Table 1. DIC, DOC, POC, TSM and PN yields (respectively $Y_{\mathrm{DIC}}, Y_{\mathrm{DOC}}, Y_{\mathrm{POC}}, Y_{\mathrm{TSM}}, Y_{\mathrm{PN}}$ ) in $\mathrm{tkm}^{-2} \mathrm{yr}^{-1}$ calculated with power law method (see Sect. 5.1 for calculation description) for the Capesterre River, Bras-David River and Vieux-Habitants River.

\begin{tabular}{|c|c|c|c|c|c|c|c|c|c|c|c|c|c|c|c|}
\hline \multirow[b]{2}{*}{ Years } & \multicolumn{4}{|c|}{ Bras-David } & \multicolumn{7}{|c|}{ Capesterre } & \multicolumn{4}{|c|}{ Vieux-Habitants } \\
\hline & $\begin{array}{l}\text { Duration } \\
\text { of the } \\
\text { record }\end{array}$ & $\begin{array}{c}Q \\
\left(m^{3} y r-1\right)\end{array}$ & $Y_{D O C}$ & $Y_{\text {DIC }}$ & $\begin{array}{l}\text { Duration } \\
\text { of the } \\
\text { record }\end{array}$ & $\begin{array}{c}Q \\
\left(m^{3} y r-1\right)\end{array}$ & $Y_{D O C}$ & $Y_{D I C}$ & $Y_{\mathrm{TSM}}$ & $Y_{\mathrm{POC}}$ & $Y_{\mathrm{PN}}$ & $\begin{array}{l}\text { Duration } \\
\text { of the } \\
\text { record }\end{array}$ & $\begin{array}{c}Q \\
\left(\mathrm{~m}^{3} \mathrm{yr}-1\right)\end{array}$ & $Y_{D O C}$ & $Y_{\text {DIC }}$ \\
\hline 2007 & $89.0 \%$ & $2.5 \times 10^{7}$ & $2.6 \pm$ & & $96.1 \%$ & $10^{7}$ & & 0.3 & & & & $89.1 \%$ & $8 \times 10^{7}$ & 0.3 & 1.0 \\
\hline 2008 & $94.2 \%$ & $2.7 \times 10^{7}$ & $2.9 \pm 0.5$ & $11.8 \pm 1.1$ & $95.2 \%$ & $6.6 \times 10^{7}$ & $7.4 \pm 0.3$ & $14.2 \pm 0.4$ & $153 \pm 19$ & $18.4 \pm 2.7$ & $1.3 \pm 0.2$ & $88.4 \%$ & $5.1 \times 10^{7}$ & $2.7 \pm 0.5$ & $11.9 \pm 1.2$ \\
\hline 2009 & $100 \%$ & $3.2 \times 10^{7}$ & $4.2 \pm 0.7$ & $12.7 \pm 1.1$ & $97.1 \%$ & $7.6 \times 10^{7}$ & $8.6 \pm 0.4$ & $15.8 \pm 0.4$ & $177 \pm 22$ & $21.2 \pm 3.1$ & $1.5 \pm 0.2$ & $39.7 \%$ & $3.6 \times 10^{7}$ & $1.9 \pm 0.3$ & $8.1 \pm 0.8$ \\
\hline 2010 & $100 \%$ & $2.0 \times 10^{7}$ & $2.4 \pm 0.4$ & $9.6 \pm 0.9$ & $83.3 \%$ & $7.4 \times 10^{7}$ & $8.6 \pm 0.4$ & $15.2 \pm 0.4$ & $213 \pm 26$ & $25.5 \pm 3.8$ & $1.7 \pm 0.3$ & $6.6 \%$ & & & \\
\hline
\end{tabular}




\section{BGD}

$9,7117-7163,2012$

Table 2. Calculations of residence times of organic carbon in soils for different tropical watersheds including the Capesterre watershed.

\begin{tabular}{|c|c|c|c|c|c|c|c|c|c|c|c|}
\hline \multicolumn{3}{|c|}{ Sites } & \multirow[t]{2}{*}{ Climate } & \multirow{2}{*}{$\begin{array}{c}\mathbf{Y}_{\mathrm{POC}} \\
\mathrm{Ckm}^{-2} \mathrm{yr}^{-1}\end{array}$} & \multirow{2}{*}{$\begin{array}{c}\mathbf{Y}_{\mathrm{DOC}} \\
\mathrm{Ckm}^{-2} \mathrm{yr}^{-1}\end{array}$} & \multirow{2}{*}{$\begin{array}{c}Y_{D I C} \\
\mathrm{tC} \mathrm{km}^{-2} \mathrm{yr}^{-1}\end{array}$} & \multirow{2}{*}{$\begin{array}{c}\mathrm{NPP}^{\mathrm{a}} \\
\mathrm{tkm}^{-2} \mathrm{yr}^{-1}\end{array}$} & \multirow{2}{*}{$\begin{array}{c}\mathrm{GPP}^{\mathrm{b}} \\
\mathrm{tkm}^{-2} \mathrm{yr}^{-1}\end{array}$} & \multicolumn{2}{|c|}{ C stock } & \multirow{2}{*}{$\begin{array}{c}\text { Residence time } \\
\text { Organic } \\
\text { carbon } \\
\text { in soils } \\
\text { yr }\end{array}$} \\
\hline & & & & & & & & & $\mathrm{tC} \mathrm{km}^{-2}$ & $\mathrm{tCkm}^{-2}$ & \\
\hline New Zealand & Waitangitaona $^{\mathrm{c}}$ & & Temperate & 39 & 2 & 3.5 & 1100 & & 28000 & 15000 & 683 \\
\hline Puerto Rico & Rio Icacos ${ }^{\mathrm{d}, \mathrm{e}}$ & & Tropical & 4 & 9 & 10 & 2190 & 3000 & 10000 & 20000 & 769 \\
\hline Amazon $\mathrm{SW}^{\mathrm{d}, \mathrm{f}}$ & & & Tropical & 1.76 & 3.15 & 5 & 2200 & 3000 & 10300 & 20000 & 2098 \\
\hline Cameroun & Mengong $^{g}$ & & Tropical & 0.575 & 5.7 & 0.31 & 2200 & 3000 & 15340 & 20000 & 2445 \\
\hline Guadeloupe & Capesterre $^{\mathrm{d}, \mathrm{h}}$ & $\begin{array}{l}2007 \\
2008 \\
2009\end{array}$ & Tropical & $\begin{array}{c}8.1 \\
18.4 \\
21.2\end{array}$ & $\begin{array}{l}4.9 \\
7.4 \\
8.6\end{array}$ & $\begin{array}{l}11.3 \\
14.2 \\
15.8\end{array}$ & 2200 & 3000 & 13000 & 20000 & $\begin{array}{c}1000 \\
504 \\
436\end{array}$ \\
\hline & & 2010 & & 25.5 & 8.6 & 15.2 & & & & & 381 \\
\hline
\end{tabular}

a NPP: Net Primary Production.

${ }^{b}$ GPP: Gross Primary Production.

c Hilton et al. (2008b); Carey et al. (2005); Whitehead et al. (2002); Coomes et al. (2002).

${ }^{\mathrm{d}}$ Baudin et al. (2007).

e McDowell and Asbury (1994).

${ }^{\dagger}$ Moreira-Turcq et al. (2003).

9 Boeglin et al. (2005)

${ }^{\mathrm{h}}$ Estimation for the Martinique soils (Blanchart and Bernoux, 2005).

\section{Tropical oceanic islands carbon export}

E. Lloret et al.

Title Page

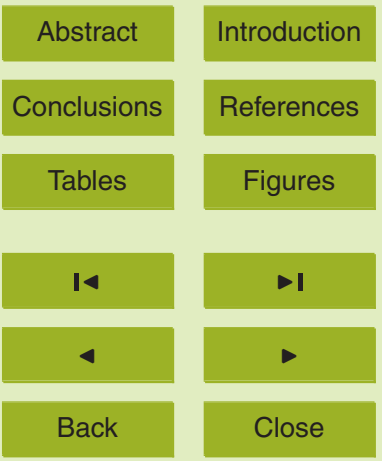

Full Screen / Esc

Printer-friendly Version

Interactive Discussion 

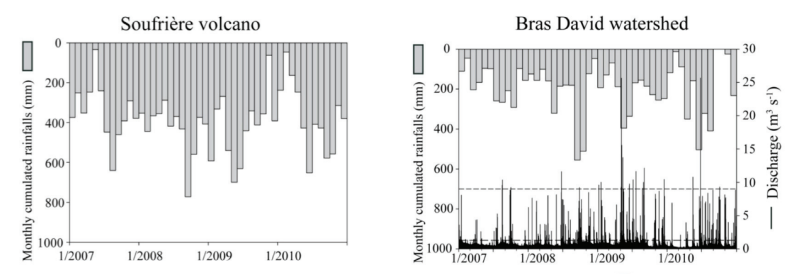

\section{BGD}

9, 7117-7163, 2012

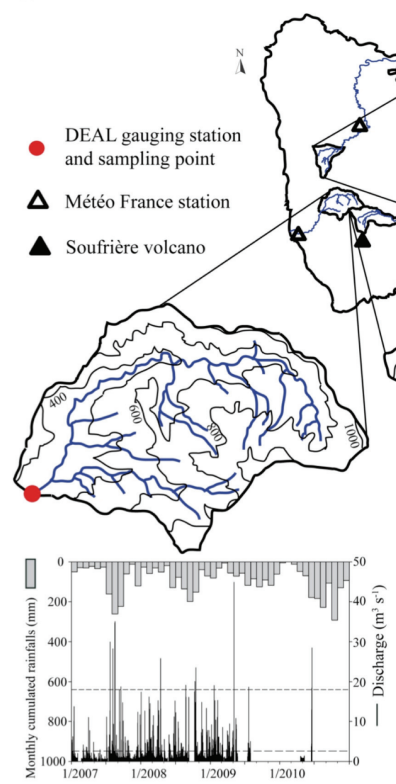

Vieux Habitants watershed
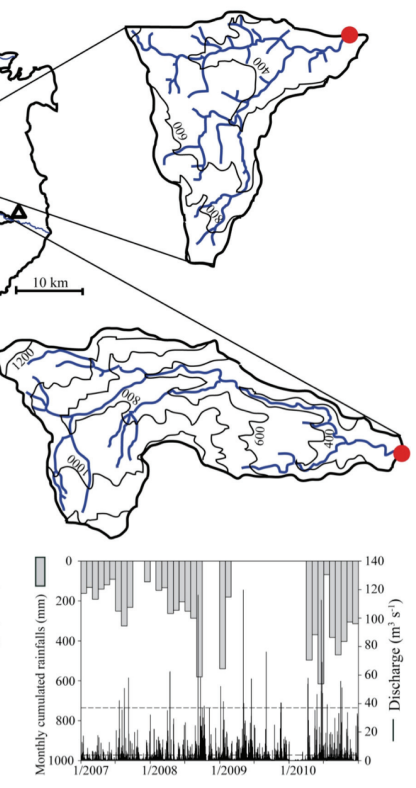

Capesterre watershed

Fig. 1. Map of the Basse-Terre with the location of the three studied watersheds. Instantaneous water discharge and monthly cumulated rainfalls are presented for each river from January 2007 to December 2010. The absence of bars or lines corresponds to an absence of measurements. Long dashes represent the minimum discharge for the flood level and short dashes represent the minimum discharge for the extreme flood level. The rainfalls at the Soufrière volcano have been corrected to the wind effect.

\section{Tropical oceanic islands carbon export}

E. Lloret et al.

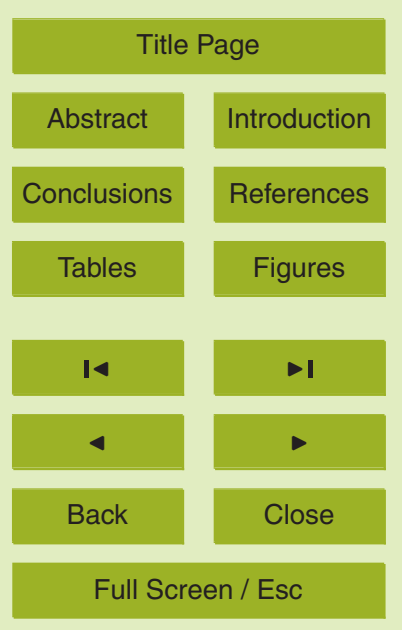

Printer-friendly Version

Interactive Discussion 
BGD

9, 7117-7163, 2012

\section{Tropical oceanic} islands carbon export
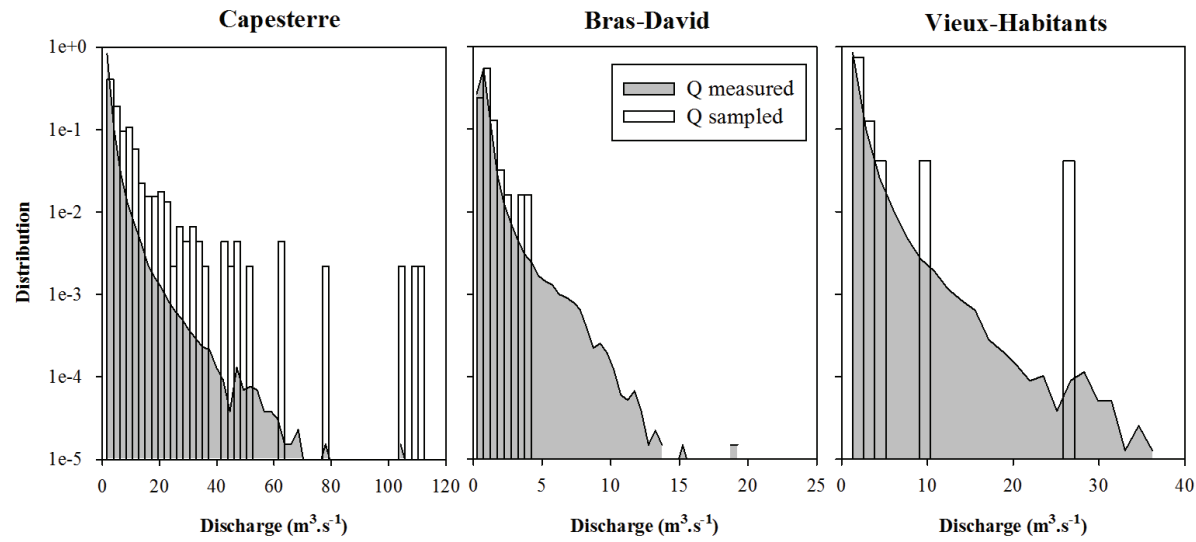

Fig. 2. Comparison between the distribution of discharges (black line) and the distribution of sampled discharges for the Capesterre, Bras-David and Vieux-Habitants rivers.

\section{E. Lloret et al.}

Title Page

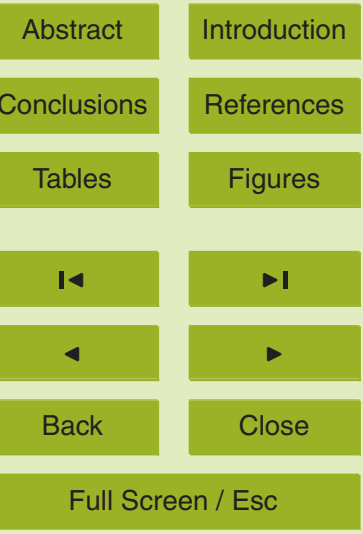

Printer-friendly Version

Interactive Discussion 


\section{BGD}

9, 7117-7163, 2012

Tropical oceanic islands carbon export

E. Lloret et al.

Title Page

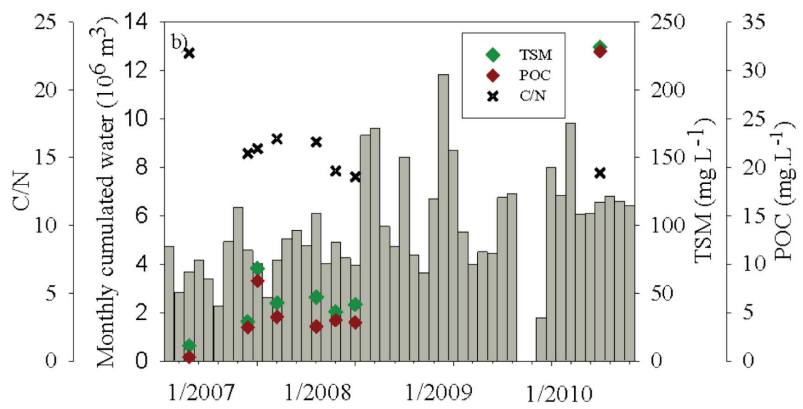

Abstract

Introduction

Conclusions

References

Tables

Figures

14

4

Back

\section{Full Screen / Esc}

Printer-friendly Version

Interactive Discussion 

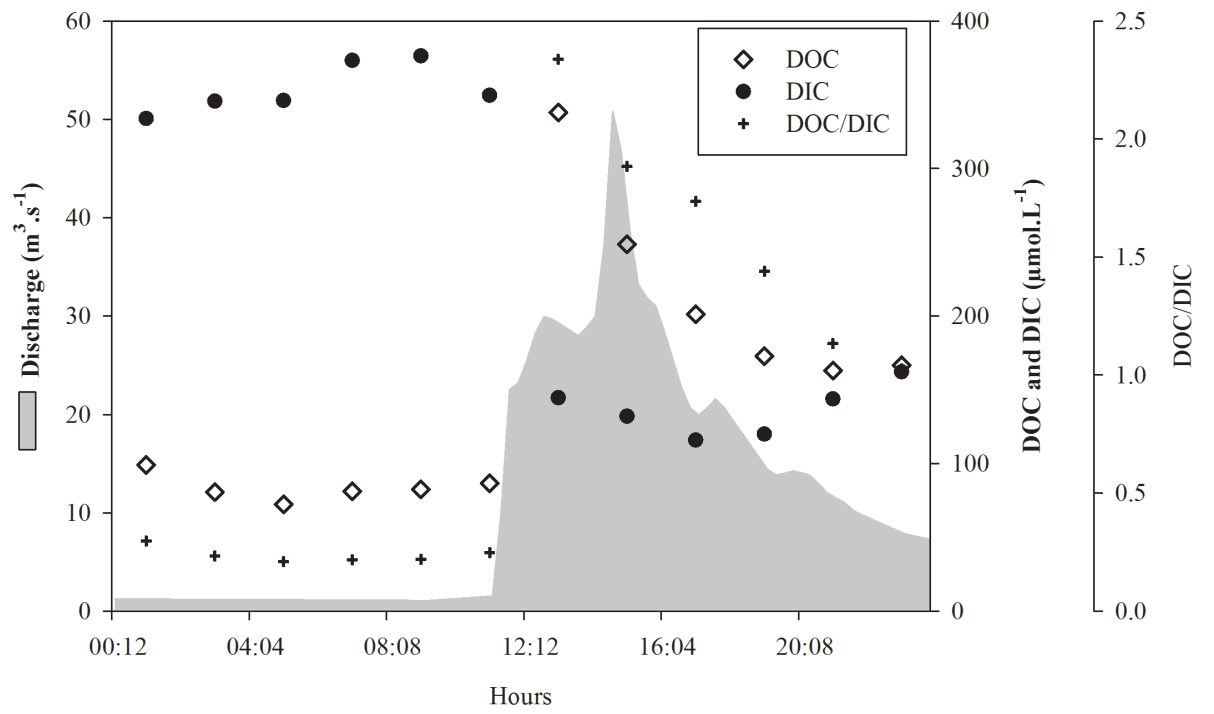

Fig. 4. Hourly follow up of an extreme event in the Capesterre River: 17 August 2007, associated to Dean Cyclone. Variations of DOC and DIC concentrations, and DOC/DIC ratios during the event.
BGD

9, 7117-7163, 2012

Tropical oceanic islands carbon export

E. Lloret et al.

Title Page

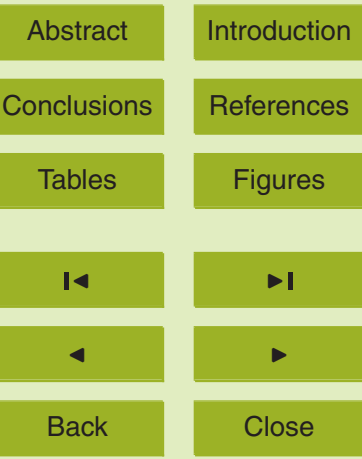

Full Screen / Esc

Printer-friendly Version

Interactive Discussion 


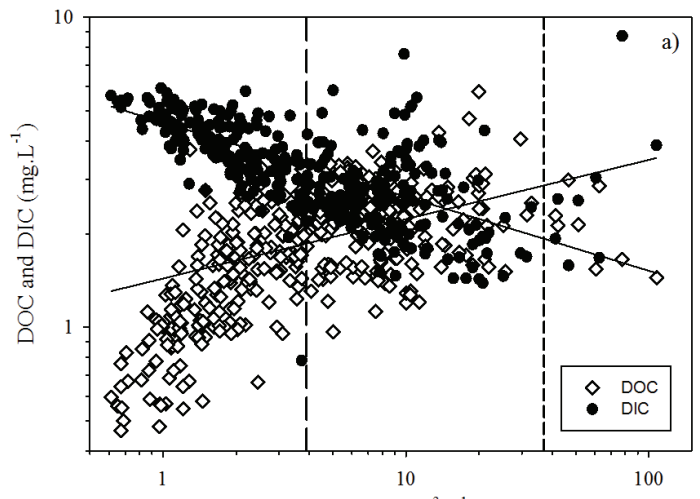

\section{BGD}

9, 7117-7163, 2012

\section{Tropical oceanic} islands carbon export

E. Lloret et al.

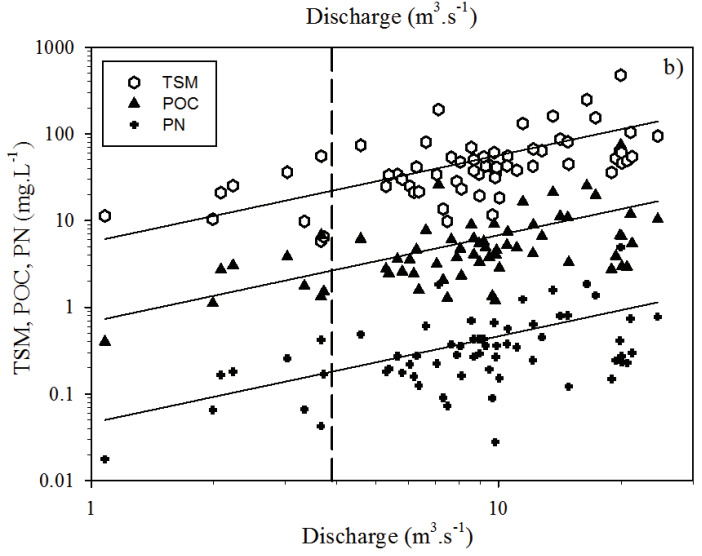

Title Page

Abstract

Introduction

Conclusions

References

Tables

Figures

I

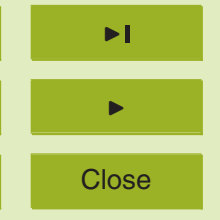

Back

Close

\section{Full Screen / Esc}

Fig. 5. DOC and DIC concentrations (a), TSM, POC and PN concentrations (b) plotted as a function of the discharge $(Q)$ for the Capesterre River. Long dashes represent the minimum discharge for the flood level and short dashes represent the minimum discharge for the extreme flood level. Lines correspond to the best fit of the data by a power law: concentration $=\alpha Q^{\beta}$ (see Supplement, Table A3).

Printer-friendly Version

Interactive Discussion 


\section{BGD}

9, 7117-7163, 2012

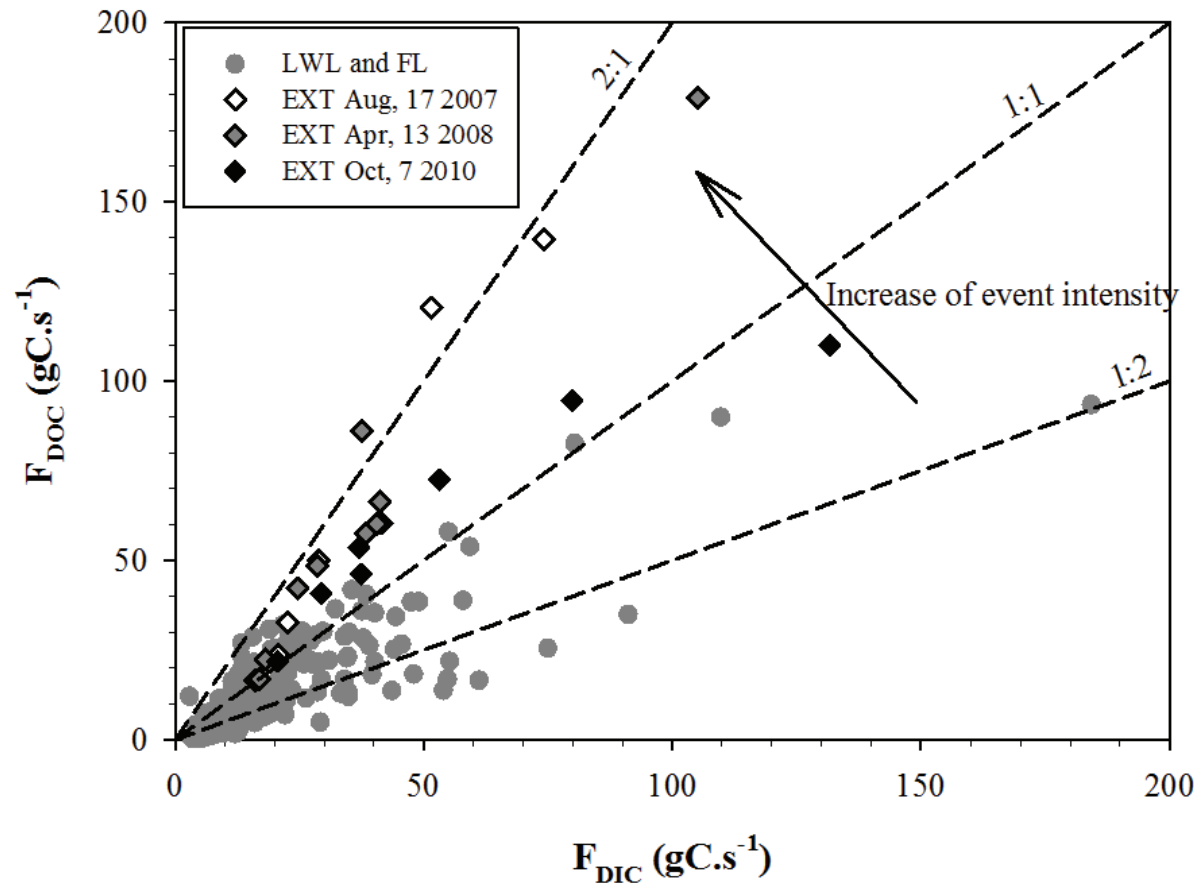

Fig. 6. DOC versus DIC fluxes (respectively $F_{\mathrm{DOC}}$ and $F_{\mathrm{DIC}}$ ), and their distribution according to the water level: low water level, floods (maximum instantaneous discharge $\geq 3.9 \mathrm{~m}^{3} \mathrm{~s}^{-1}$ ) and extreme floods (maximum instantaneous discharge $\geq 37.0 \mathrm{~m}^{3} \mathrm{~s}^{-1}$ ).

\section{Tropical oceanic} islands carbon export

E. Lloret et al.

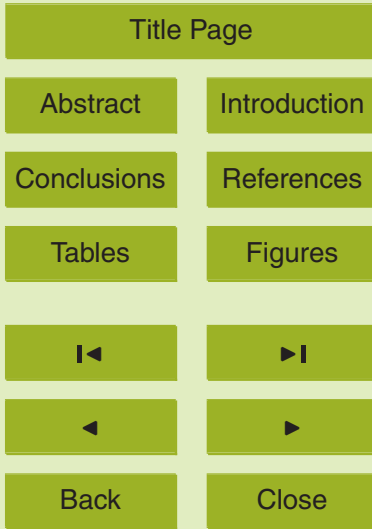

Full Screen / Esc

Printer-friendly Version

Interactive Discussion 


\section{BGD}

9, 7117-7163, 2012

Tropical oceanic islands carbon export

E. Lloret et al.
Ext. Flood

- Flood

- Low Water Level
Title Page

Abstract

Conclusions

Tables

14

4

Back
Introduction

References

Figures

$>$ I

$>$

Close
Full Screen / Esc

Printer-friendly Version

Interactive Discussion 


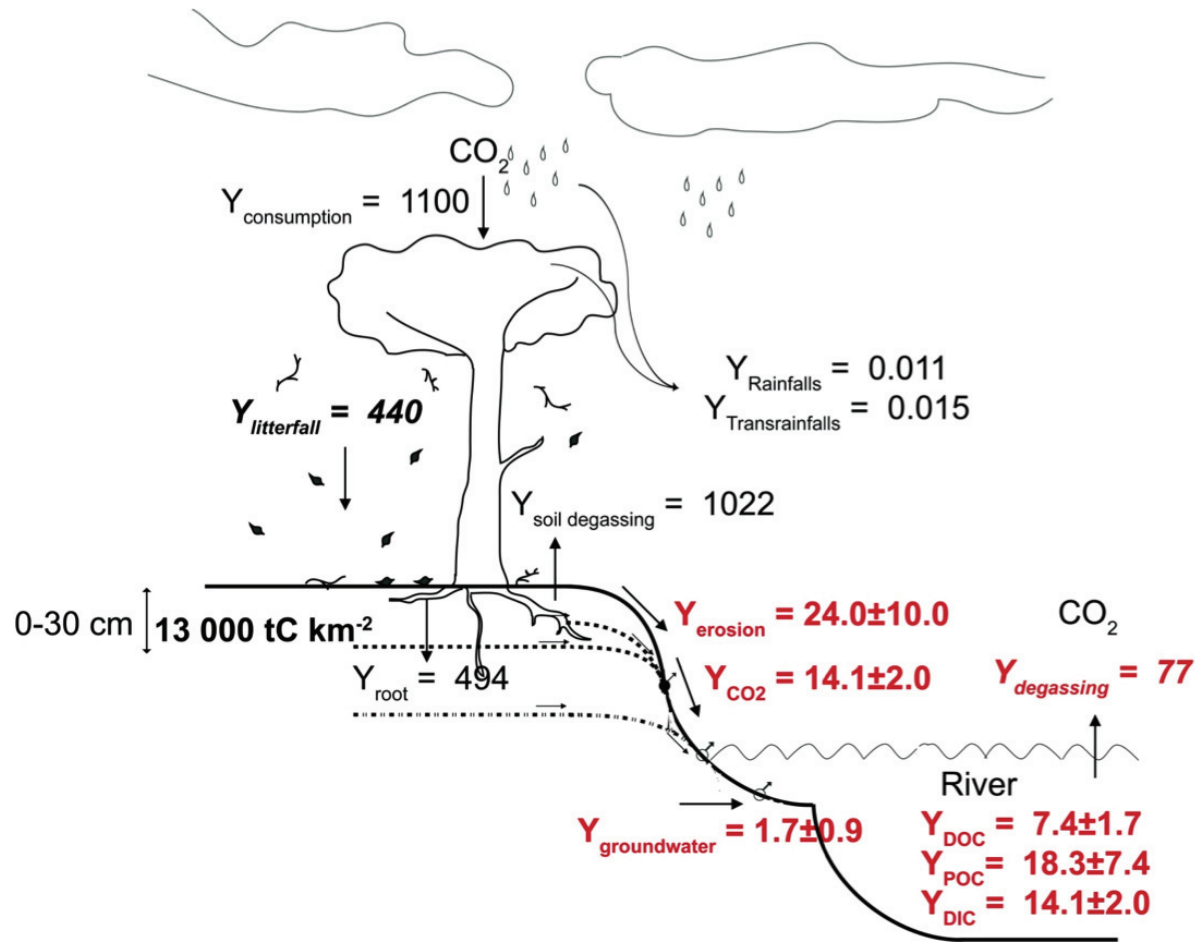

Fig. 8. Summary of the carbon mass balance at the Guadeloupean watershed. The yields are in $\mathrm{tC} \mathrm{km}^{-2} \mathrm{yr}^{-1}$. Underlined values were obtained for our watershed. Other values are from other tropical watersheds (Bray and Gorham, 1964; Madge, 1965; Hopkins, 1966; Rodin et al., 1967; Blanchart and Bernoux, 2005; Silver et al., 2005; Heartsill-Scalley et al., 2007; Lloret, 2010).

\section{BGD}

9, 7117-7163, 2012

Tropical oceanic islands carbon export

E. Lloret et al.

Title Page

Abstract Introduction

Conclusions References

Tables

Figures

14

4

Back

Close

\section{Full Screen / Esc}

Printer-friendly Version

Interactive Discussion 


\section{BGD}

9, 7117-7163, 2012
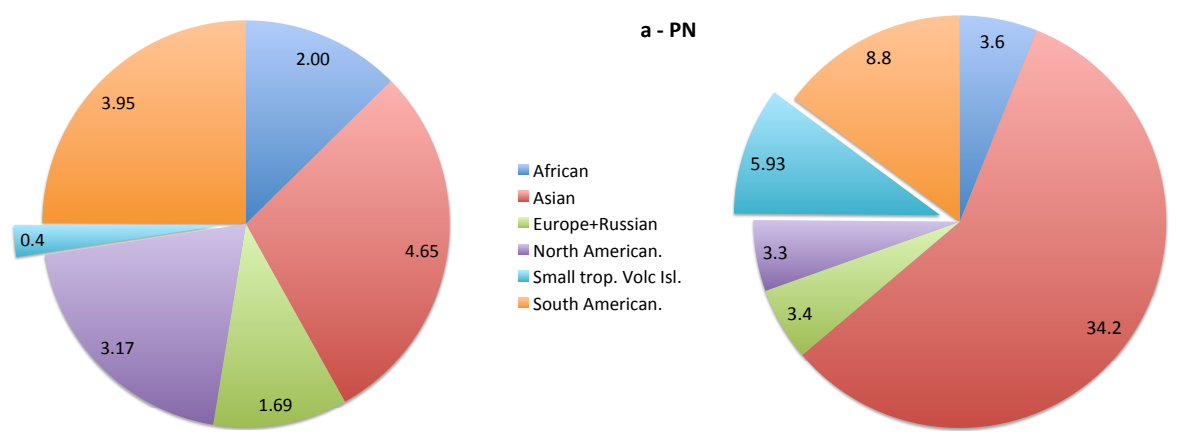

b- POC

African

- Asian

Europe+Russian

North American

- Small trop. Volc Is

- South American.

Fig. 9. Comparison of annual fluxes of PN (a) and POC (b) $\left(\mathrm{Tg} \mathrm{yr}^{-1}\right)$ from small volcanic and tropical mountainous islands and each continent. The mean fluxes of each continent have been calculated to sum literature values of mainly large rivers. South American rivers: Amazon, Parana and Orinoco Rivers, North American rivers: Mississippi, Mackenzie, St. Lawrence, Yukon and Columbia, Asian rivers: Changjiang, Huang He, Ganges/Brahmaputra and Indus, African rivers: Zaire/Congo, Niger and Nile, European and Russian Rivers: Yenisei, Ob, Lena, Danube, Kolyma, Rhine, Rhone, Garonne and Po (Moreira-Turcq et al., 2003; Ludwig et al., 1996b (and associated references); Dittmar and Kattner, 2003; Gebhardt et al., 2004; Holmes et al., 2002; Rachold et al., 2004; Meybeck and Ragu, 1996; Romankevich and Artemyev, 1985; Dittmar and Kattner, 2003).

\section{Tropical oceanic islands carbon export}

E. Lloret et al.

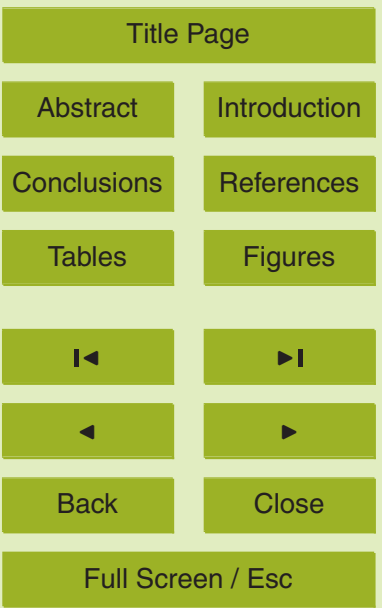

Printer-friendly Version

Interactive Discussion 
BGD

9, 7117-7163, 2012

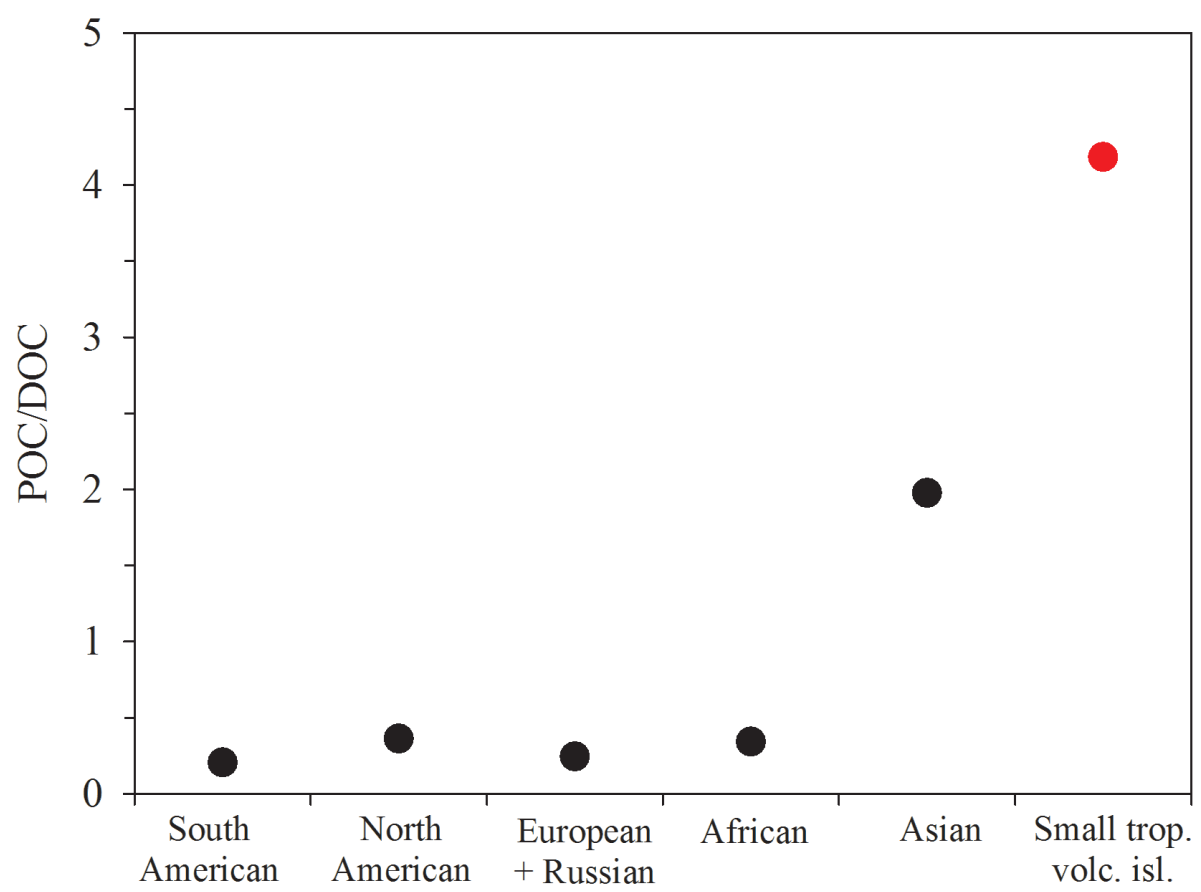

Fig. 10. POC/DOC ratio for small volcanic and tropical mountainous islands and for each continent.

\section{Tropical oceanic islands carbon export}

E. Lloret et al.

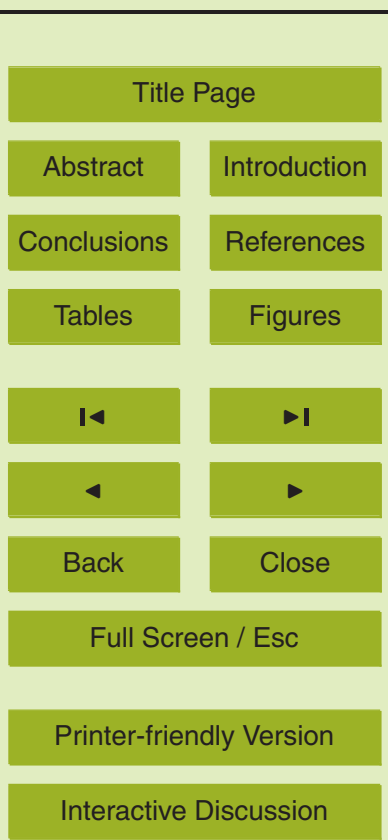

Interactive Discussion 